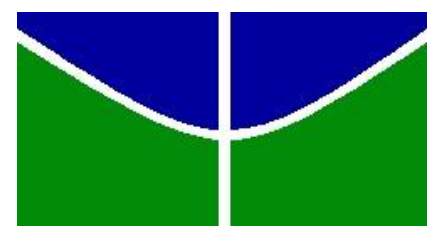

UNIVERSIDADE DE BRASÍLIA - UnB

Programa de Pós-Graduação em

Nanociência e Nanobiotecnologia

FERNANDA LOPES RODOVALHO

ELABORAÇÃO DE NANOSORBENTES MAGNÉTICOS À BASE NANOPARTICULAS DE Co0,5Mn0,5Fe2O4 FUNCIONALIZADAS COM POLIDIMETILSILOXANO COMO PROTÓTIPOS PARA REMEDIAÇÃO DE ÁGUAS CONTAMINADAS COM DERIVADOS DE COMBUSTÍVEIS FÓSSEIS

BRASÍLIA - DF 


\author{
Universidade de Brasília \\ Instituto de Ciências Biológicas \\ Programa de Pós-Graduação em Nanociência e Nanobiotecnologia
}

FERNANDA LOPES RODOVALHO

\title{
ELABORAÇÃO DE NANOSORBENTES MAGNÉTICOS À BASE NANOPARTICULAS DE Co0,5Mn0,5Fe2O4 FUNCIONALIZADAS COM POLIDIMETILSILOXANO COMO PROTÓTIPOS PARA REMEDIAÇÃO DE ÁGUAS CONTAMINADAS COM DERIVADOS DE COMBUSTÍVEIS FÓSSEIS
}

\begin{abstract}
Dissertação apresentada ao programa de Pós-Graduação em Nanociências e Nanobiotecnologia, do Instituto de Ciências Biológicas da Universidade de Brasília, como parte integrante dos requisitos para obtenção do Título de Mestre em Nanociências e Nanobiotecnologia.
\end{abstract}

Orientador: Prof ${ }^{\circ}$. Dr. Marcelo Henrique Sousa

BRASÍLIA - DF 
Dissertação de Mestrado

Fernanda Lopes Rodovalho

Título:

"Elaboração de nanosorbentes magnéticos à base de nanopartículas de $\mathrm{Co}_{0,5} \mathrm{Mn}_{0,5} \mathrm{Fe}_{2} \mathrm{O}_{4}$ funcionalizadas com polidimetilsiloxano como protótipos para remediação de água contaminada com derivados de combustíveis"

Comissão Examinadora:

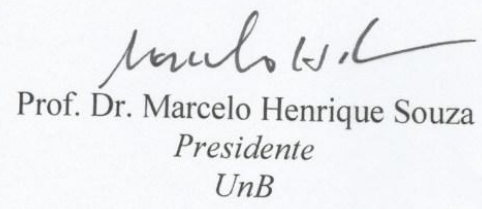

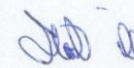

Prof. Dr. Sebastião William da Silva Membro Titular Interno vinculado ao Programa $U n B$
Prof. Dr. Alex Fabtano Coryet:Campos Membro Pitular Interno nä vinculado ao programa

$U n B$ 
Para Jacqueline e Fernando pelo amor dedicado.

Para Anna Paula e Natália pela amizade genuína. Para o Eduardo pelo sopro de vida e luz no meu caminho. Para Letícia por ensinar que o amor existe independente dos laços sanguíneos. Agradeço também por ter o olhar mais puro do mundo. Para Elisa Lopes pelo companheirismo e amor em todos os momentos. Para os pequenos Rafael, Felipe e Maitê que me enchem de alegria e esperança.

Para Valéria Morgana que eu tenho como mãe. Para Ivana Andrade pela compreensão, paciência e espera 


\section{AGRADECIMENTOS}

Não haveria outra maneira de começar os agradecimentos se não por Deus, o grande propulsor de toda a vida existente no Universo. Graças a Ele nasci na família que me foi destinada, tive o filho que me foi emprestado nessa jornada, possuo o veículo físico necessário para meus afazeres na Terra, agradeço também as tarefas que me são dadas me fazendo evoluir e melhorar a cada dia. A compreensão e o entendimento chegam até nós por meio do tempo e devemos ter a sabedoria para enxergar as melhorias necessárias para o nosso crescimento. É importante que sigamos o exemplo de Jesus que por meio da caridade foi um grande mestre e é a luz que nos inspira a sempre seguir os seus passos..

Obviamente agradeço aos meus pais, Jacqueline e Fernando, pela educação que me disponibilizaram, as normas que me impuseram e os "nãos" que me disseram, necessários para me ensinar os limites que são impostos pela vida. Graças a eles pude chegar à universidade e ampliar meus conhecimentos científicos. Agradeço também a todo o amor e preocupação que me deram.

As minhas irmãs, Anna Paula e Natália, agradeço por serem sempre as minhas melhores amigas e me apoiarem quando precisei. Vocês são meu porto seguro.

A Elisa Lopes agradeço por estar presente em todos os momentos especiais e alegres na minha vida, sua amizade e amor estão marcados em mim.

Ao Rodrigo Veraneio agradeço por ser o irmão que a vida me deu. Seus conselhos são muito importantes para mim, obrigada pelas palavras amigas. 
Agradeço ao Eduardo, meu filho amado, por chegar de forma inesperada e me mostrar o sublime amor de mãe. Você me ensina a cada dia a ser melhor e é por você que sempre viverei.

A minha pequena Letícia agradeço pela oportunidade de conviver com você, tenho certeza que me ensinas muitas coisas que estão além dessa vida material.

As minhas primas e tios agradeço pelo aconchego familiar que sempre esteve presente em minha vida. Vocês me inspiram amor e confiança.

Agradeço a tia Gracinha, bisavó Geralda, aos avôs Negrinho e Jairon e a avó Dinora pelas bênçãos que me destinam dos céus. A Bárbara Peixoto agradeço pela breve, mas iluminada passagem pela minha vida, obrigada por se tornar uma boa amiga, a dor da perda nos faz amadurecer e compreender os desígnios divinos. A saudade é grande. Obridada à avó Lurdinha pelos momentos de felicidade marcados em minha memória.

À madrinha Valéria Morgana e ao Padrinho Agenor obrigada pelo amor de mãe e pai, aprendi muita coisa convivendo com a fé e dedicação de vocês.

Agradeço a Ivana Andrade por ter entrado na minha vida sem que eu esperasse. Dizem que as boas coisas vêm com o tempo e as especiais de repente.

Por fim, agradeço ao meu orientador Marcelo Henrique, seus ensinamentos e tolerância foram o suporte para que eu realizasse esse trabalho.

OBRIGADA 


\section{RESUMO}

Nesse trabalho, nanopartículas magnéticas, à base de ferrita mista de cobalto e manganês funcionalizadas com polidimetilsiloxano com terminações carboxila (PDMSCOOH), foram sintetizadas, visando aplicações nanobiotecnológicas na área ambiental. O interesse de elaborar o material foi a remediação de recursos hídricos contaminados com derivados de petróleo (BTEX). As nanopartículas de óxido magnético foram sintetizadas por coprecipitação alcalina e, após tratamento de superfície, foram peptizadas em meio ácido. Então, condições ótimas de concentração e pH foram estabelecidas para uma máxima funcionalização dos nanogrãos com o PDMSCOOH. A estrutura espinélio foi confirmada por difração de raios $\mathrm{X}$ e dosagens químicas levaram à fórmula química $\mathrm{Mn} 0,5 \mathrm{Co} 0,5 \mathrm{Fe}_{2} \mathrm{O} 4$ para o material sintetizado. Por microscopia eletrônica de transmissão, nanopartículas com morfologia do tipo esférica e com diâmetro médio de $\sim 13 \mathrm{~nm}(0,21$ de polidispersão $)$ foram encontradas. O sucesso da funcionalização foi verificado por espectroscopia de absorção no infravermelho, que mostrou a modificação da superfície após a complexação pelo ligante. No modelo proposto, os grupos carboxila do $\mathrm{PDMSCOOH}$ se ligam aos sítios superficiais das nanopartículas, enquanto a extremidade apolar da cadeia fica livre para interagir com o contaminante orgânico. Medidas de magnetização mostraram um comportamento ferromagnético para as nanopartículas que se alteram após funcionalização. A eficiência de remoção de contaminantes foi feita pelo estudo de isotermas de adsorção em amostras contendo água e tolueno, interagindo com as nanopartículas funcionalizadas, por analise do teor de carbono total antes e depois dessa interaçção.

Palavras chave: nanopartículas magnéticas, funcionalização, polidimetilsiloxano, remediação ambiental, tolueno, BTEX. 


\begin{abstract}
In this work, magnetic nanoparticles based on cobalt and manganese mixed ferrites, functionalized using polidimetisiloxane (PDMS) with carboxyl endings (PDMSCOOH), were synthesized in view of nanobiotechnological applications in environmental area. In the interest of developing the material was the remediation of contaminated water with oil products (BTEX). The magnetic oxide nanoparticles were synthesized using alkaline coprecipitation route and, after a surface treatment, were peptized in acidic medium. Thus, optimal conditions of ligand concentration and $\mathrm{pH}$ were set up to a maximal nanograin functionalization with PDMSCOOH. After capping, nanoparticles were redispersed into aqueous solution. Spinel structure was confirmed for nanoparticles by $\mathrm{x}$ ray (XRD) experiments and chemical dosages led to chemical formula $\mathrm{Mn} 0.5 \mathrm{Co} 0.5 \mathrm{Fe} 2 \mathrm{O} 4$. By transmission electronic microscopy (TEM), spherical-like morphology and $~ 12,9 \mathrm{~nm}$ sized ( 0.21 of polydispersity index) nanostructures were found. The success of functionalization was verified by infra-red absorption microscopy (FTIR) which showed the nanoparticle surface modification after ligand complexation. In the proposed model, carboxyl groups of PDMSCOOH were attached to the superficial sites while extremity apolar chain terminations were free to interact with organic contaminant. Magnetization measurements showed a ferromagnetic behavior for nanoparticles that change after functionalization. The contaminant removal efficiency was made by the study of adsorption isotherms in samples containing water and toluene, interacting with the functionalized nanoparticles, for analysis of total carbon (TOC) content before and after the interaction.
\end{abstract}

Keywords: magnética nanoparticles, funcionalization, polidimetilsiloxane, environmental remediation, toluene, BTEX. 


\section{LISTA DE FIGURAS}

Figura 1 - Estrutura simplificada dos BTEX - o anel benzênico está presente em todos os compostos.

Figura 2 - Fluxograma proposto por Shackelfordd das etapas de um projeto de remediação.

Figura 3 - Representação do mecanismo da SVE. A aplicação do vácuo auxilia na remoção de agentes voláteis e semi voláteis do solo. A técnica permite a transferência em massa da contaminação do solo para a atmosfera.

Figura 4 - Representação da técnica de biorremediação. Microrganismo metaboliza um contaminante orgânico liberando no final do processo $\mathrm{CO}_{2}$ e $\mathrm{H}_{2} \mathrm{O}$ (EPA, 2001b).

Figura 5 - Representação de uma cela unitária da estrutura cristalográfica tipo espinélio em que as esferas verdes representam os átomos de oxigênio, as vermelhas os cátions dos sítios tetraédricos e as amarelas simbolizam os cátions nos sítios octaédricos.

Figura 6 - Comportamento de dipolos magnéticos, simbolizados pelas setas escuras, na presença e ausência de campo magnético externo aplicado. Com base no alinhamento desses dipolos magnéticos, os materiais são classificados como diamagnético, paramagnético, ferromagnético, ferrimagnético e antiferromagnético.

Figura 7 - Etapas realizadas no processo de síntese das ferritas de cobalto e manganês.

Figura 8 - Diagrama esquemático representando a estabilidade coloidal, as cargas de superfície e os grupos associados a essas cargas, em função do $\mathrm{pH}$. p $K_{\mathrm{a} 1}$ e $\mathrm{p} K_{\mathrm{a} 2}$ representam os valores das constantes de dissociação ácida dos grupos de superfície e PCN representa o ponto isoelétrico, em $\mathrm{pH} \sim 7$ para as NPMs aqui estudadas.

Figura 9 - Ferrofluido a base de ferritas de cobre e manganês. O magnetismo do material é claramente perceptível pela ação do imã.

Figura 10 - Difratograma de raios x das nanoparticulas sintetizadas. A ampliação é do pico 311 .

Figura 11 - Imagem da microscopia eletrônica de transmissão da amostra de nanoparticulas de ferritas de cobalto e manganês não funcionalizadas.

Figura 12 - Imagem em alta resolução das nanoparticulas a base de ferrita de cobalto e manganês por microscopia eletrônica de transmissão.

Figura 13 - Histograma das NPM de ferrita cobalto e manganês não funcionalizadas.

Figura 14-Representação da molécula de PDMS. 
Figura 15 - Representação da complexação da superfície das NPMs pelo ligante PDMSCOOH)via carboxilato.

Figura 16 - Diagramas de especiação da superfície das NPMs (em vermelho) e dos ligantes (em azul). As constantes de dissociação ácidas das NPs (p $\left.K_{\mathrm{a} 1} \mathrm{e} \mathrm{p} K_{\mathrm{a} 2}\right)$ e do ligante ( $\mathrm{p} K \mathrm{~L})$, assim como o pH ideal de complexação, estão indicados na figura.

Figura 17- Difratograma de raios $\mathrm{x}$ das nanoparticulas funcionalizadas (vermelho) e não funcionalizadas (preto).

Figura 18 - Espectros de FTIR das amostras analisadas: Ferrofluido puro, ferrofluido funcionalizado e PDMS. Os picos ajudam a caracterizar a composição química dos materiais e colaboram com a análise para concluir se o PDMS se aderiu, ou não, a superfície das nanoparticulas.

Figura 19 - Imagem de MET das nanopartículas funcionalizadas.

Figura 20 - Curva de magnetização versus campo magnético aplicado para as NPs não funcionalizadas. O gráfico em detalhe mostra a histerese.

Figura 21 - Representação da interação do PDMS com a superfície das nanopartículas. No frasco contendo a amostra é possível perceber duas fases: tolueno + nanopartículas funcionalizadas e água. As características macroscópicas da amostra corroboram com a hipótese de complexação.

Figura 22 - Representação da dispersão das nanoparticulas funcionalizadas com PDMS em solução contendo tolueno. Após a adsorção do contaminante pelas nanopartículas é possível reciclar o material separando-as do efluente utilizando um imã.

Figura 23 - Gráfico do percentual de tolueno removido em função da relação da massa de nanopartículas sobre a massa de tolueno em cada amostra.

Figura 24 - Isoterma de adsorção de tolueno pelas NPM 


\section{LISTA DE QUADROS}

Quadro 1 - Solubilidade dos BTEX em água.

Quadro 2 - Relação da capacidade de adsorção de carvões ativos de acordo com o diâmetro médio dos poros.

Quadro 3 - Relação simplificada das técnicas de caracterização com suas respectivas funções.

Quadro 4 - Curvas de calibração para carbono total (TC) e carbono inorgânico (IC). 


\section{Lista de tabelas}

Tabela 1 - Parâmetros de magnetização para nanoparticulas funcionalizadas e não funcionalizadas.

Tabela 2 - Parâmetros de concentração e massa para os testes de adsorção.

Tabela 3 - Parâmetros de adsorção obtidos do ajuste matemático das isotermas 


\section{LISTA DE ABREVIATURAS E SIGLAS}

BTEX ...........Benzeno,Tolueno, Etilbenzeno e Xilenos

DRX ...........Difração de Raio X

FM .............Fluidos Magnéticos

FTIR ..........Fourrier Transform Infrared Spectroscopy

IC ...............Carbono Inorgânico

M ................Metal

MAG ...........Medidas de Magnetização

Ms ...............Magnetização de Saturação

Mr ...............Magnetização Remanente

NPs ...............Nanopartículas

NPM .............Nanopartícula Magnética

OMS .............Organização Mundial de Saúde

PAS …..........Poliaquilsiloxanos

PAS-COOH ..Poliaquilsiloxanos carboxil - terminados

PDMS ...........Polidimetilsiloxano

POMS ..........Polioctimetilsiloxanos

SVE .............Soil Vapor Extraction (Extração de Vapor do Solo)

TC ...............Carbono Total

TEM ...........Transmission Electron Microscopy (Microscopia Eletrônica de transmissão)

TOC ............Teor de Carbono Total

VSM ............Vibrating Sample Magnetometer (Magnetometria de Amoatra Vibrante) 
O desenvolvimento da ciência, tanto no campo moral como no laboratorial, é o alicerce para construirmos uma sociedade consolidada na educação, igualdade e tecnologia, pois onde se consagra a luz do conhecimento às perspectivas para o futuro se tornam as melhores possiveis. 


\section{SUMÁRIO}

1.INTRODUÇÃO

1.1 CONTAMINAÇÃO DE ÁGUAS SUBTERRÂNEAS POR HIDROCARBONETOS

1.2 DESCONTAMINAÇÃO DE DERIVADOS DE PETRÓLEO DE ÁGUA SUBTERRÂNEA

1.3 A NANOTECNOLOGIA NA DESCONTAMINAÇÃO AMBIENTAL

1.3.1 NANOPARTÍCULAS MAGNÉTICAS DE ÓXIDOS DE FERRO

2. OBJETIVOS

3. MATERIAIS E MÉTODOS

3.1 SÍNTESE DAS NANOPARTÍCULAS DE FERRITA DE COBALTO

E MÂNGANES

3.2 FUNCIONALIZAÇÃO DAS NANOPARTÍCULAS COM PDMS

3.3 CARACTERIZAÇÃO DAS AMOSTRAS

3.3.1 MICROSCOPIA ELETRÔNICA DE TRANSMISSÃO (MET)

3.3.2 ESPECTROSCOPIA DE ABSORÇÃO NO INFRAVERMELHO COM TRANSFORMADA DE FOURRIER

3.3.3 DIFRAÇÃO DE RAIO X (DRX)

3.3.4 MEDIDAS DE MAGNETIZAÇÃO

3.4 TESTES DE ADSORÇÃO

4. RESULTADOS

4.1 SÍNTESE DAS NANOPARTÍCULAS MAGNÉTICAS

4.2 FUNCIONALIZAÇÃO DAS NANOPARTÍCULAS MAGNÉTICAS COM PDMSCOOH

4.3 TESTES DE ADSORÇÃO 53

5. CONCLUSÕES E PERSPECTIVAS

REFERÊNCIAS BIBLIOGRÁFICAS 
Introdução 


\section{Introdução}

Atualmente, a área da nanociência ganha crescente espaço e importância no cenário de inovação tecnológica mundial. Nesse contexto, materiais como nanosorbentes, nanocatalisadores, nanopartículas bioativas e membranas catalíticas nanoestruturadas têm sido cada vez mais empregadas no desenvolvimento de processos e métodos para remediação e monitoramento de sistemas contaminados com rejeitos químicos ${ }^{1}$. Dentre os inúmeros materiais, as nanopartículas magnéticas (NPM), que apresentam grande variabilidade de aplicações, desempenham um papel muito importante para remediação da poluição química em ambientes aquáticos ${ }^{2}$.

A utilização de partículas magnéticas nanoestruturadas como ferramenta para o processo de remoção de poluentes em água apresenta inúmeras vantagens em relação aos métodos convencionais de descontaminação ambiental ${ }^{3}$ sendo, a principal delas, a capacidade de adsorver os contaminantes (em geral não magnéticos), o que permite a separação pela ação de um campo magnético externo. Em geral, nanosorbentes magnéticos são elaborados pela funcionalização de nanopartículas magnéticas com ligantes específicos que apresentam afinidade química com os contaminantes ${ }^{4}$.

Um dos principais causadores de poluição por derivados de petróleo em áreas urbanas são os postos revendedores de combustíveis. No Brasil, a região Centro-Oeste tem a maior incidência de acidentes com vazamentos e contaminação por hidrocarbonetos ${ }^{5}$. Os principais contaminantes são os hidrocarbonetos monoaromáticos benzeno, etilbenzeno, tolueno e xileno, compostos que podem causar câncer e problemas no sistema nervoso central. No Brasil, o Ministério da Saúde, por meio da Portaria 518/04, determina que os valores máximos permitidos (VMP) para benzeno, tolueno, etilbenzeno e xilenos em água para consumo humano são de 5, 170, 200 e 300 
$\mathrm{mg} / \mathrm{L}$, respectivamente ${ }^{6}$. A maioria dos vazamentos tem como causa o vencimento do prazo da vida útil dos tanques de armazenamentos de combustíveis subterrâneos, em média 25 anos. Na década de 1970 houve um aumento significativo do número dos postos de gasolina no Brasil e esse aumento está diretamente relacionado com o crescimento dos acidentes com vazamentos de combustíveis ${ }^{7}$. Esses contaminantes liberados nos vazamentos de combustíveis poluem o solo e as águas subterrâneas, principalmente por meio da zona de recarga. Nesse contexto, a utilização de nanomateriais magnéticos e a filtração magnética se tornam interessantes para a remediação desses corpos hídricos.

De fato, nanocompósitos magnéticos à base de nanopartículas de magnetita funcionalizadas com polialquilsiloxanos (PAS) foram utilizados para a remoção de hidrocarbonetos em concentrações da ordem de ppm, de águas contaminadas ${ }^{8}$. Nesse processo, polidimetilsiloxano (PDMS) e polioctilmetilsiloxano (POMS) carboxilterminados foram adicionados a dispersões aquosas de nanopartículas magnéticas, funcionalizando-as ${ }^{9}$. Esses polímeros apresentam um segmento eletricamente carregado que complexa a superfície da nanopartícula e outro - uma cadeia carbônica apolar - que se estende ao solvente, garantindo interação com os contaminantes apolares. Após serem introduzidas na amostra contaminada, as nanopartículas funcionalizadas sorvem os contaminantes, que podem ser carregados com o auxilio de um campo magnético externo.

A eficiência desse sistema exige, portanto, uma grande área superficial, garantida pelas reduzidas dimensões dos nanocompósitos; uma alta magnetização de saturação, que pode ser ajustada controlando-se a composição e estrutura dos nanogrãos e uma boa escolha de ligantes que devem, por um lado, interagir fortemente com a nanopartícula e, por outro, ter grande afinidade com os contaminantes. É com a intenção 
de otimizar esses parâmetros, que este trabalho pretende mostrar um caráter inovador na elaboração de nanocompósitos magnéticos a serem utilizados na remediação de recursos hídricos contaminados com derivados de petróleo.

Na prática, em escala nanométrica, a magnetita (ou maguemita), que vem sendo utilizada para esses propósitos, possui magnetização de saturação reduzida ( 50 emu/g) quando comparada a outras ferritas, como as mistas de cobalto e manganês, que podem apresentar magnetização de saturação de até $90 \mathrm{emu} / \mathrm{g}{ }^{10}$, além de propriedades magnéticas diferenciadas, nessa faixa de tamanho. Também, parâmetros de síntese permitem controlar o diâmetro dos nanogrãos ${ }^{11}$, de tal forma a estabelecer uma boa relação de custo/benefício entre área superficial (quanto menor a nanopartícula, maior o poder de sorção de contaminantes) e magnetização de saturação (quanto maior a nanopartícula, maior a magnetização de saturação). Em relação à funcionalização, é interessante a utilização de polialquilsiloxanos carboxil-terminados (PAS-COOH), uma vez que a interação entre ligante e nanopartícula é forte se dá pela complexação dos metais de superfície pelo grupo carboxilato. De maneira vantajosa, a funcionalização que utiliza esses PAS-COOH pode ser feita em meio aquoso, ao contrário de polialquilsiloxanos tradicionais que exigem meios não-aquosos ${ }^{12}$.

De fato, uma vez que o grupo complexante $\mathrm{COO}^{-}$é gerado por meio da ionização do grupo carboxila, a força iônica e o pH do meio devem ser controlados durante o processo de síntese para ajustar, não só a concentração de moléculas ionizadas, mas também a carga de superfície da nanopartícula, permitindo sua funcionalização ${ }^{13}$. Entretanto, existem poucos estudos, principalmente que investiguem a interação microscópica entre esses PAS-COOH e as mudanças de interface (i.e. afinidade entre o contaminante e o nanocompósito) que esse tipo de funcionalização aporta aos nanogrãos magnéticos. 
Mais especificamente, este trabalho propõe a elaboração de nanopartículas de ferritas mistas de manganês-cobalto $\left(\mathrm{Mn}_{\mathrm{x}} \mathrm{Co}_{1-\mathrm{x}}\right) \mathrm{Fe}_{2} \mathrm{O}_{4}$ com magnetização de saturação elevada e sua funcionalização com polidimetilsiloxano carboxil-terminado, PDMSCOOH, a fim de se obter um nanocompósito magnético para aplicação na descontaminação de águas contendo poluentes derivados de combustíveis. Nessa etapa, os parâmetros ótimos de funcionalização foram investigados e estabelecidos, além de serem elucidadas a interação nanocompósito-contaminante e otimizados o poder de aplicação desses nanosorbentes, investigados por isotermas de adsorção.

\subsection{Contaminação de águas subterrâneas por hidrocarbonetos}

Estudos sobre a contaminação ambiental começaram a ganhar espaço no meio técnico e científico na década de $1980{ }^{14}$. Atualmente o assunto se tornou uma das prioridades dos profissionais especializados em pesquisas relacionadas ao meio ambiente.

É conhecido que o sistema ecológico, primordialmente, é constituído pela interação de todos os seres vivos com o ambiente e pela convivência inter e intraespecífica, elementos minerais, naturais e vivos relacionam de maneira intrínseca de forma equilibrada e harmoniosa. Na prática, porém, esse equilíbrio é ameaçado por ações antrópicas resultando em desordem ambiental e exploração desmedida dos recursos existentes no ambiente. O aumento da densidade populacional está diretamente relacionado com o crescente consumo de recursos naturais uma vez que atividades antropogênicas ocasionam acelerada escassez e contaminação dos mesmos. O "boom" populacional acarreta em maior consumo de energia, alimento, água, vestuário e tecnologia para garantir o conforto da vida moderna. As demandas da sociedade atual 
exigem crescente avanço científico, este por sua vez, ganha notório espaço no cenário tecnológico por suprir as necessidades existentes no mercado. A velocidade com que a tecnologia avança é facilmente perceptível, as inúmeras engenhocas tecnológicas estão presentes no cotidiano e se tornam rapidamente ultrapassadas sendo substituídas, constantemente, por modelos que apresentam inovadoras funções. Esse avanço científico é importantíssimo para o desenvolvimento da sociedade moderna, porém gera um enorme impacto ambiental, pois propicia o aumento e acumulo de lixo e a exploração e contaminação de recursos naturais.

Inúmeros agentes contaminantes agridem os recursos naturais, o solo, a água e o ar estão expostos a subprodutos nocivos que são liberados por fábricas e oriundos do processo de urbanização. Esses contaminantes além de prejudicarem o ambiente acarretam problemas de saúde em seres humanos. Metais pesados como mercúrio, chumbo, níquel e alumínio, por exemplo, são facilmente encontrados no solo e água ${ }^{15}$. O contato de mamíferos com esses elementos, incluindo o Homem, pode causar o desenvolvimento de câncer, danos no DNA e intensos efeitos colaterais causados por intoxicação ${ }^{16}$. Outros agentes contaminantes frequentemente encontrados no solo e em recursos hídricos são os hidrocarbonetos monoaromáticos. Esse tipo de contaminação, normalmente, ocorre devido aos vazamentos dos tanques subterrâneos que armazenam gasolina ${ }^{7}$. Em relação aos gases nocivos que contaminam o ar, destacam - se o dióxido de carbono e o dióxido de enxofre, emitidos principalmente na queima de combustíveis por veículos e indústrias. Em seres humanos, a frequente inalação desses gases está diretamente relacionada a problemas de saúde como: asma, pneumonia, doença pulmonar obstrutiva, doença isquêmica do coração e doença do aparelho circulatório ${ }^{17}$.

Todas as formas de contaminação devem ser estudadas visando à melhoria da qualidade do ambiente, iniciativas de conservação e prevenção precisam ser tomadas 
com o intuito de diminuir o máximo possível às diversas contaminações em todas as esferas ambientais. Entre os incontáveis agentes contaminantes que assolam os recursos hídricos disponíveis naturalmente, o foco do trabalho foi à contaminação por hidrocarbonetos monoaromáticos devido ao fato desse contaminante ser o principal causador da má qualidade das águas que abastecem as cidades. Cabe destacar que os postos revendedores de combustíveis são os vetores primordiais de contaminação por hidrocarbonetos das águas presentes no subsolo terrestre ${ }^{18}$.

A rápida e desmedida expansão industrial petrolífera e o crescimento de indústrias petroquímicas, bem como o desenvolvimento urbano e industrial, contribuíram significativamente para a deteriorização do solo e água. O interesse de investir em atividades de exploração petrolífera está diretamente relacionado à contaminação de aquíferos por compostos orgânicos $(\mathrm{CO})$ uma vez que são os constituintes primordiais de combustíveis fósseis. Esses compostos são, na maioria das vezes, tóxicos e carcinogênicos prejudicando a saúde humana.

O petróleo é uma mistura de inúmeros $\mathrm{CO}$, com predominância de hidrocarbonetos, e sua composição varia de acordo com a sua procedência ${ }^{19}$. É um material derivado da transformação aeróbia e anaeróbia por bactérias e decomposição da matéria orgânica de plantas aquáticas e animais pré-históricos. O acúmulo dos seres decompostos ao longo dos milênios em oceanos, lagos e pântanos, se transformou, em condições favoráveis de temperatura e pressão $\left(\sim 150^{\circ} \mathrm{C}\right)$, em petróleo.

Os CO comumente encontrados em solos e águas subterrâneas são os hidrocarbonetos monoaromáticos de petróleo, hidrocarbonetos poliaromáticos, orgânicos halogenados e defensivos agrícolas ou pesticidas. Devido ao crescente interesse em exploração de petróleo e o aumento do consumo de gasolina para suprir a demanda do ser humano, o trabalho abordou a contaminação por hidrocarbonetos 
monoaromáticos presentes em combustíveis: benzeno, tolueno, etilbenzeno e xileno os BTEX - conforme mostrado na figura 1.

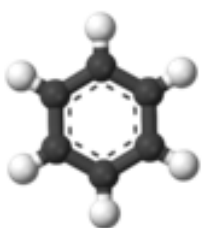

Benzeno

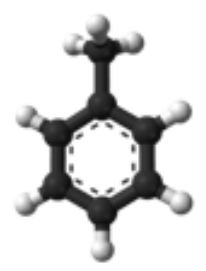

Tolueno

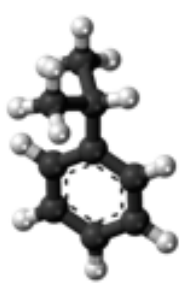

Etilbenzeno

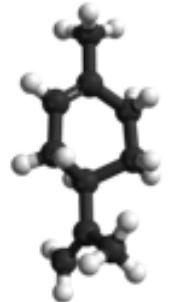

p-Xileno

Figura 1 - Estrutura simplificada dos BTEX - o anel benzênico está presente em todos os compostos.

Os BTEX geralmente são mais tóxicos que os compostos alifáticos com o mesmo número de carbonos e possuem maior mobilidade por possuírem maior solubilidade em água. Dentre os BTEX, o benzeno é o mais tóxico e, além de ser um composto cancerígeno pode causar enjoos, aceleração do ritmo cardíaco, cefaleia, irritação no estômago, tremores e confusão mental ${ }^{20}$. A Organização Mundial da Saúde (OMS) estabeleceu valores de $10 \mathrm{ppb}$ de benzeno em água de abastecimento público, enquanto nos Estados Unidos esse limite é de $5 \mathrm{ppb}$ e na Europa é de $1 \mathrm{ppb}$. No Brasil, a portaria 2914/2011 estabeleceu um valor de 5 ppb.

A água subterrânea representa, em termos globais, 97\% de toda água doce disponível para consumo humano e é de extrema importância preservar esse tipo de recurso livre de contaminação. As regiões mais afetadas em aquíferos são principalmente os lençóis mais rasos que ficam próximos de esgotos e/ou postos de gasolina. Em média, a vida útil de um tanque subterrâneo que armazena combustível em 
postos revendedores é de 25 anos, após esse período aumentam as chances de vazamento devido à oxidação dos tonéis de armazenamento. A fiscalização acerca da manutenção ou troca desses tanques é falha, devido a isso é comum o escape de gasolina, diesel e álcool contaminando os aquíferos.

As áreas urbanas, por conterem maior número de postos de gasolina, são as principais causadoras da contaminação de recursos hídricos subterrâneos. No Brasil existem aproximadamente 27.000 postos de gasolina, e o consumo de combustíveis aumenta a cada dia, em 1995, por exemplo, o consumo de álcool, gasolina e diesel foi cerca de 153 milhões de litros por dia ${ }^{21}$. Cidades como São Paulo e Joinville (SP) já possuem legislação sobre o tema, e o crescente interesse envolvendo potenciais vazamentos ganha relevância conforme as pesquisas sobre contaminação por combustíveis fósseis avançam. Em um estudo realizado em Joinville pela Prefeitura local, apenas um dos 65 postos de gasolina presentes na cidade, não continha nenhum problema relacionado a vazamento de tanques ou contaminação do lençol freático ${ }^{22}$.

A gasolina fabricada no Brasil tem na formulação uma considerável parte de etanol $(20 \%)$ e hidrocarbonetos BTEX ${ }^{23}$. Produtos oxigenados, compostos de enxofre, compostos metálicos e compostos de nitrogênio são encontrados em baixas concentrações na composição desse combustível ${ }^{24}$. Os hidrocarbonetos são bastante solúveis em etanol, e este por sua vez, é altamente miscível em água, sendo assim, a presença do etanol na composição da gasolina propicia a solubilidade dos BTEX em água. Em contato com a água subterrânea esses compostos, devido ao maior caráter hidrofílico em comparação aos outros componentes da gasolina, serão os primeiros a alcançarem o lençol freático ${ }^{25}$.

Por serem agentes imunodepressores do sistema nervoso central e causarem problemas hepáticos e leucemia, quando em exposições crônicas, esses contaminantes 
são considerados altamente tóxicos, sendo que o benzeno é o mais prejudicial à saúde humana. Exposições agudas, ou seja, o contato com altas concentrações em curto período de tempo, por inalação ou ingestão pode levar uma pessoa à morte.

Devido os graves riscos a saúde ocasionados pelo contato com os BTEX, a legislação vem se tornando cada vez mais rigorosa e restritiva em relação a concentrações aceitáveis desses produtos orgânicos em águas de consumo. No Brasil, a Portaria 1.469/2000, do Ministério da Saúde, estabelece os seguintes limites permitidos para os hidrocarbonetos em água potável: $5 \mu \mathrm{g} / \mathrm{L}$ no caso do benzeno, $170 \mu \mathrm{g} / \mathrm{L}$ para o tolueno, $200 \mu \mathrm{g} / \mathrm{L}$ para o etilbenzeno e $300 \mu \mathrm{g} / \mathrm{L}$ para o xileno. O quadro 1 mostra as solubilidades dos BTEX em água ${ }^{26}$.

\begin{tabular}{|c|c|c|}
\hline Nome & Peso Molecular & Solubilidade em Água \\
\hline Benzeno & 78,11 & $1780 \mathrm{mg} / \mathrm{L}$ \\
\hline Tolueno & 92,10 & $500 \mathrm{mg} / \mathrm{L}$ \\
\hline Etilbenzeno & 106,17 & $150 \mathrm{mg} / \mathrm{L}$ \\
\hline Xileno & 106,17 & $170 \mathrm{mg} / \mathrm{L}$ \\
\hline
\end{tabular}

Quadro 1 - Solubilidade dos BTEX em água (CETESB, 2000).

\subsection{Descontaminação de derivados de petróleo de águas subterrâneas}

A fim de detectar a contaminação e propor maneiras de recuperar áreas atingidas, Schackelford propôs o fluxograma apresentado na figura 2 para as etapas de um projeto de remediação. De fato, existem diversas metodologias associadas à descontaminação de hidrocarbonetos, dissolvidos ou puros, em águas subterrâneas. Extração de vapor do solo (SVE), biorremediação, adsorção em carvão ativo, entre outras, são algumas das técnicas comumente empregadas para a remoção desses 
produtos orgânicos. Os processos citados podem ser aplicados no controle de plumas (contaminação), tratamento de águas subterrâneas e/ou descontaminação de solos. Essas metodologias demandam muito tempo para alcançarem os resultados desejados e dependem de alto investimento financeiro para a aplicação ${ }^{27}$.

A técnica de extração de vapor do solo é conhecida também como SVE (Soil Vapor Extraction), é utilizada apenas em “zonas não saturadas", ou seja, na região que se encontra imediatamente abaixo da superfície topográfica e acima do nível freático. Nessa região os espaços entre as partículas estão preenchidos por gases, essencialmente vapor d’água e ar atmosférico e água no estado líquido ${ }^{28}$. Tendo em vista que os agentes contaminantes migram do solo para o lençol freático e podem contaminar nascentes e aquíferos essa técnica é utilizada não apenas para limpar solo, mas também para evitar a contaminação de recursos hídricos. 


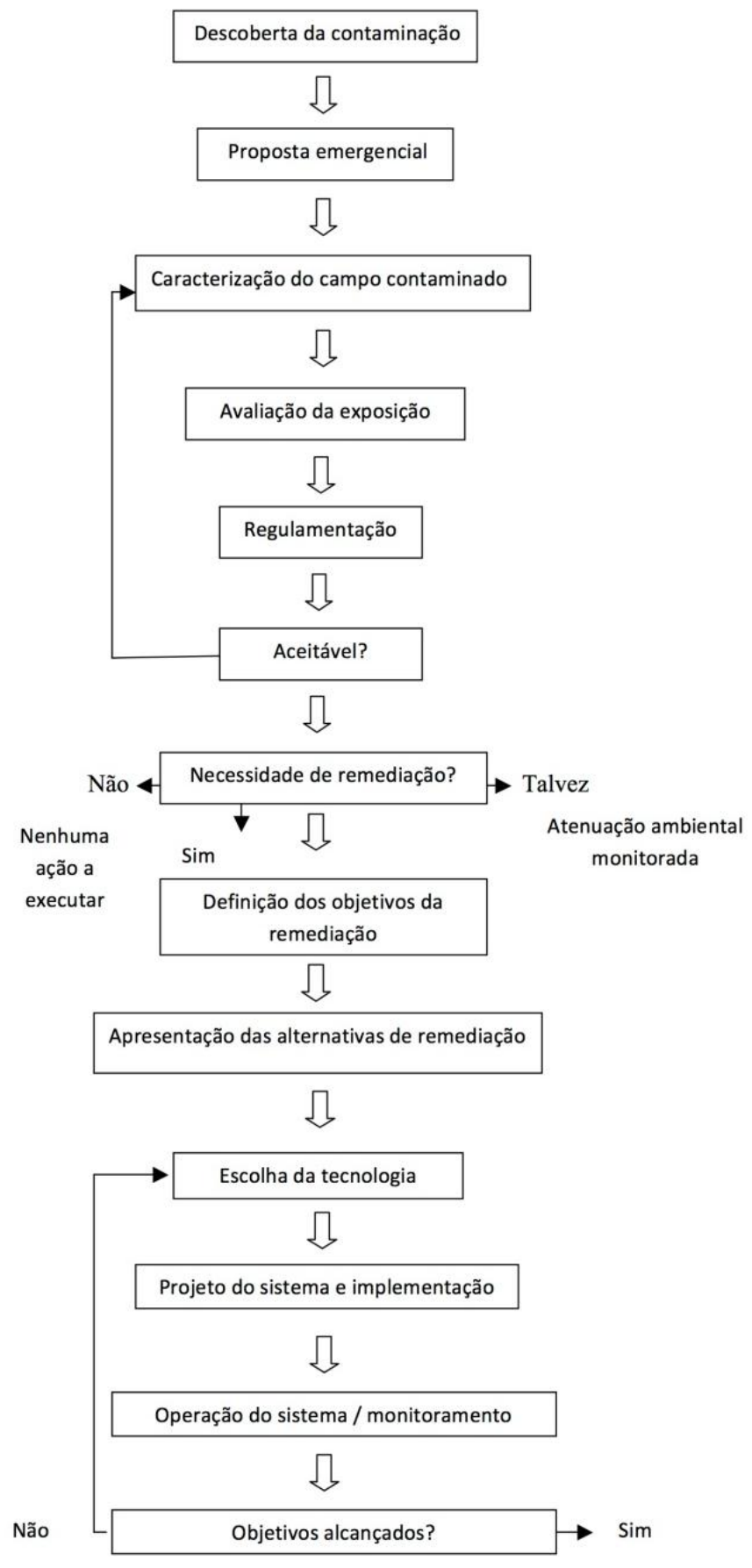

Figura 2 - Fluxograma proposto por Shackelfordd das etapas de um projeto de remediação.

Em geral, a SVE tem como princípio a aplicação de vácuo em pontos estratégicos do solo a fim de induzir o fluxo controlado de ar e, consequentemente, remover os agentes contaminantes. Nessa técnica os gases extraídos são necessariamente submetidos a processos de tratamentos de vapores antes de serem 
lançados na atmosfera, como exemplifica a figura $3^{29}$. Existem dois pré-requisitos básicos para a aplicação da SVE, o primeiro é que o solo deve possuir uma fase gasosa, através da qual o ar contaminado irá passar e o segundo é que os contaminantes que serão retirados do solo devem ter a capacidade de se transferir de outras fases (orgânica, sólida e líquida) para a fase gasosa na presença de vácuo. Essa segunda condição limita a utilização da SVE a remoção de compostos voláteis e semivoláteis.

Como todos os processos físicos de remediação ambiental, a SVE não destrói os agentes contaminantes, a técnica apenas propicia a transferência em massa desses agentes de um local para o outro, sem que haja a destruição dos mesmos ${ }^{30}$.

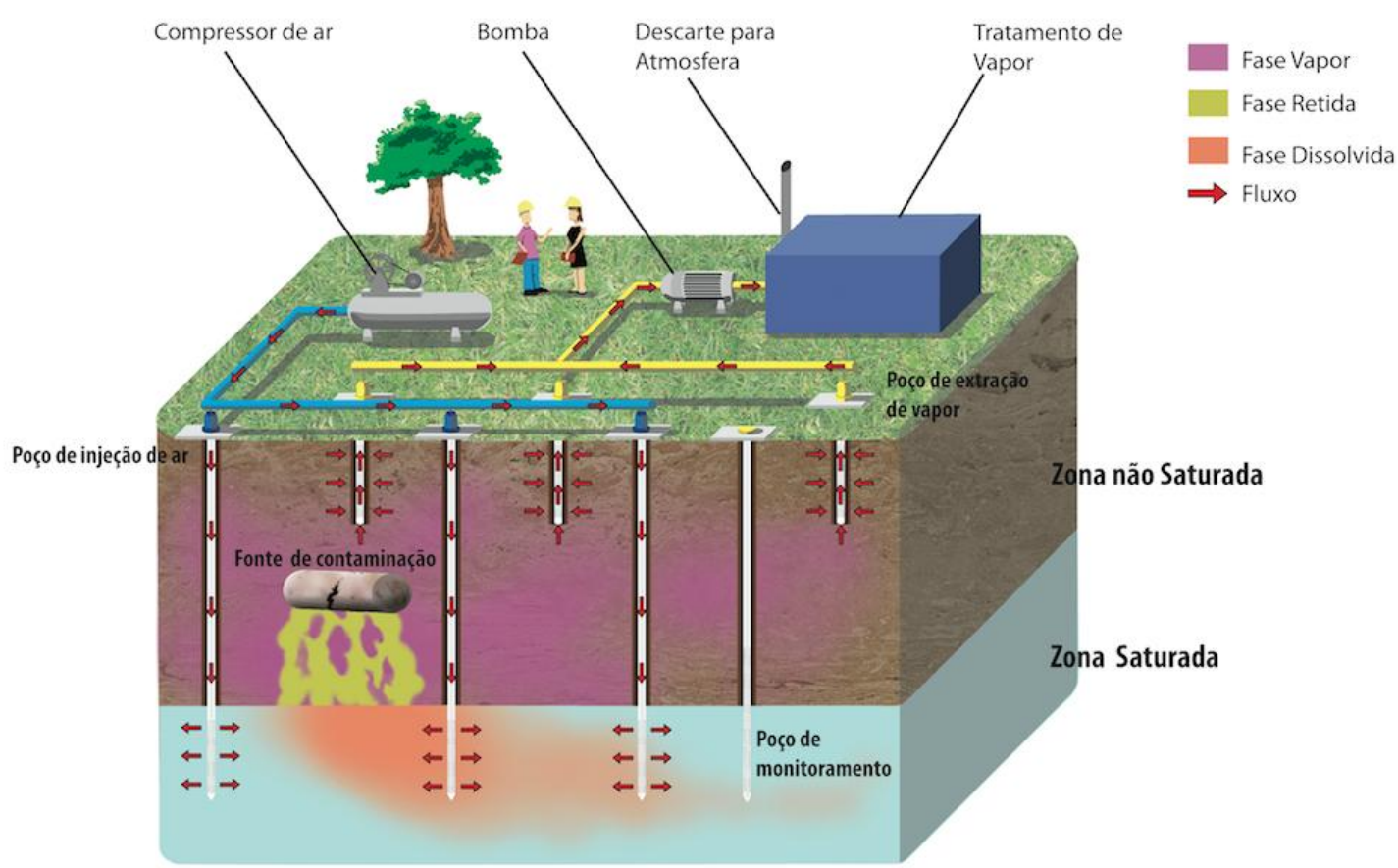

Figura 3- Representação do mecanismo da SVE. A aplicação do vácuo auxilia na remoção de agentes voláteis e semi voláteis do solo. A técnica permite a transferência em massa da contaminação do solo para a atmosfera.

A biorremediação é uma técnica comumente utilizada para remoção de derivados de petróleo em solo e água, tem como princípio a utilização de reações 
bioquímicas mediadas por microrganismos para a retirada desses contaminantes ${ }^{31}$. Os agentes biológicos empregados na técnica são capazes de modificar ou decompor os poluentes alvos, mineralizando - os e tranformando -os em gás carbônico, biomassa e água. Estratégias de biorremediação incluem: a utilização de microrganismos autóctones, ou seja, do próprio local, sem qualquer interferência de tecnologias ativas de remediação (biorremediação intrínseca ou natural); a adição de agentes estimulantes como nutrientes, oxigênio e biossurfactantes (bioestimulação); e a inoculação de consórcios microbianos enriquecidos (bioaumento) ${ }^{32}$. A biorremediação, apesar de um custo mais baixo comparada às outras técnicas, é de difícil aplicabilidade por necessitar de transporte de nutrientes ou receptores/elétrons e no controle de aclimatação e condições ideais para a realização do processo ${ }^{33}$.

Fatores como o tipo e permeabilidade do solo, profundidade do nível de água, concentração de minerais, potencial redox (Eh), pH e temperatura são limitantes para a aplicação da biorremediação, podendo tornar inviável a utilização dessa técnica de descontaminação caso os parâmetros citados não estejam em acordo com as condições necessárias. A figura 4 mostra de forma simplificada o principio básico da biorremediação.

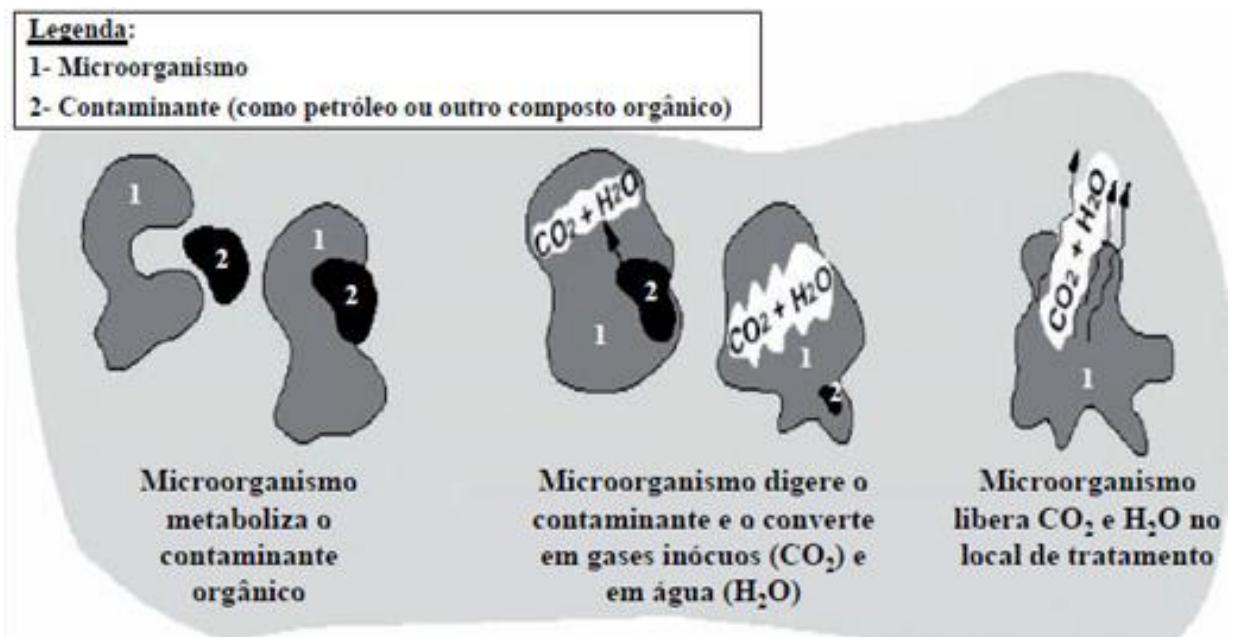


Figura 4 - Representação da técnica de biorremediação. Microrganismo metaboliza um contaminante orgânico liberando no final do processo $\mathrm{CO}_{2}$ e $\mathrm{H}_{2} \mathrm{O}$ (EPA, 2001b).

Os carvões ativados são empregados industrialmente para a descontaminação de águas, efluentes líquidos e gases de exaustão, podem ser fabricados a partir de diversos precursores carbonáceos, como a turfa, por exemplo. A utilização de carvões ativados como adsorvente de contaminantes em meios líquidos e gasosos se dá devido as propriedades texturais e natureza química de sua superfície ${ }^{34}$.

Esses materiais possuem estruturas porosas e apresentam uma forma microcristalina. Quando ativados, a porosidade interna aumenta e a capacidade de adsorção é maior. Os carvões contêm micro, meso e macroporos em sua estrutura, porém a porção relativa varia de acordo com o processo de fabricação e precursor carbonáceo utilizado. De acordo com a International Union of Pure and Applied Chemistry (IUPAC), a classificação dos poros se dá pela capacidade de adsorção como mostra a quadro 2 . 


\begin{tabular}{|c|c|c|}
\hline Tipo de poro & Diâmetro médio $(\theta \mathrm{m})$ & Função Principal \\
\hline Microporos & $\theta \mathrm{m}<2 \mathrm{~nm}$ & $\begin{array}{l}\text { Contribuempara maioria } \\
\text { da área superficial que } \\
\text { proporciona alta } \\
\text { capacidade de adsorção } \\
\text { para moléculas de } \\
\text { dimensões pequenas, tais } \\
\text { como gases e solventes } \\
\text { comuns. }\end{array}$ \\
\hline Mesoporos & $2 . \mathrm{nm}<\theta \mathrm{m}<50 \mathrm{~nm}$ & $\begin{array}{l}\text { São importantes para a } \\
\text { adsorção de moléculas } \\
\text { grandestais como corantes } \\
\text { e proporcionam a maioria } \\
\text { da área superficial para } \\
\text { carvões impregnados com } \\
\text { produtos químicos. }\end{array}$ \\
\hline Macroporos & $\theta \mathrm{m}>50 \mathrm{~nm}$ & $\begin{array}{l}\text { São nomalmente } \\
\text { considerados } \\
\text { importância para a } \\
\text { adsorção e sua função é } \\
\text { servir como meio de } \\
\text { transporte para as } \\
\text { moléculas gasosas. }\end{array}$ \\
\hline
\end{tabular}

Quadro 2 - Relação da capacidade de adsorção de carvões ativos de acordo com o diâmetro médio dos poros ${ }^{34}$.

\subsection{A nanotecnologia na descontaminação ambiental}

A nanotecnologia, entretanto, propõem formas mais eficientes, simplificadas e de menor custo para amenizar o problema da contaminação de águas. A elaboração de nanomateriais com capacidade de remover contaminantes como metais pesados e derivados de petróleo de recursos hídricos demonstra ser de aplicação eficaz e menos dispendiosa financeiramente. Existem três ramos dentro da área ambiental nas quais se esperam grandes benefícios provenientes da nanotecnologia, são elas: a prevenção de poluição no ambiente, remediação da poluição já existente e detecção e monitoramento de poluição ${ }^{35}$. No que tange o ramo de remediação ambiental a utilização de nanopartícula magnéticas é interessante devido a características como alta capacidade 
de adsorção (garantida pela grande área superficial), grande resistência mecânica, atividade catalítica e magnetismo ${ }^{36,37}$.

Dentre os diversos materiais elaborados na área da nanotecnologia as nanopartículas magnéticas de ferro são amplamente utilizadas para remoção de metais pesados, sílica e nitratos em águas de consumo ${ }^{38}$, são utilizadas também na composição de espumas magnéticas para a remoção de petróleo em águas salgadas ${ }^{39}$. Outros materiais que podem ser utilizados para sintetizar nanopartículas magnéticas são os óxidos de ferro que, por serem menos propensos a oxidação, apresentam vantagens sobre as nanopartículas de ferro ${ }^{40}$.

\subsubsection{Nanopartículas magnéticas de óxidos de ferro}

Os óxidos de ferro são encontrados facilmente na esfera global, são distribuídos na litosfera, atmosfera, hidrosfera e biosfera. Devido a grande abundancia natural e a facilidade de síntese em laboratórios, esses compostos são bastante utilizados na área de inovação tecnológica. Denomina-se óxidos de ferros os compostos formados pelos elementos químicos ferro $(\mathrm{Fe})$ com oxigênio $(\mathrm{O})$, pode-se citar, como exemplo, a magnetita $\left(\mathrm{Fe}_{3} \mathrm{O}_{4}\right)$, maguemita $\left(\gamma-\mathrm{Fe}_{2} \mathrm{O}_{3}\right)$ e hematita $\left(\alpha-\mathrm{Fe}_{2} \mathrm{O}_{3}\right)$. São reconhecidos como hidróxi e óxido hidróxi de ferro os compostos que são formados pelos elementos químicos ferro com íon hidroxila tais como goetita $(\alpha-\mathrm{FeOOH})$ e outros ${ }^{41}$.

Desses óxidos de ferro, a magnetita e maguemita são os mais utilizados e estudados em áreas como biomedicina e biotecnologia (remediação ambiental), pois apresentam estabilidade química, biocompatibilidade, baixa toxicidade e grande área superficial, características que as tornam amplamente utilizadas na química, física e biologia ${ }^{42}$. Atualmente tem-se sintetizado nanopartículas de óxidos de ferro com 
novas propriedades e funções, devido à alta razão entre área superficial e volume e propriedades como o superparamagnetismo ${ }^{43}$, esses materiais podem ser utilizados para diversos fins.

Os óxidos de ferro são classificados de acordo com sua estrutura cristalográfica, no caso da magnetita e maguemita a cristalografia é do tipo espinélio, ou seja, possuem um empacotamento cúbico nos quais os interstícios são parcialmente preenchidos com $\mathrm{Fe}^{2+}$ ou $\mathrm{Fe}^{3+}$, podendo ter coordenação octaédrica ou tetraédrica. As propriedades das nanoparticulas de óxidos de ferro são diretamente proporcionais a suas dimensões, morfologia e cristalografia. Graças as suas características diferenciadas, já citadas anteriormente, a aplicação de nanopartículas magnéticas vem mostrando um promissor avanço para descontaminação de recursos hídricos ${ }^{44}$.

As ferritas são uma combinação de ferro e óxidos de outros metais, geralmente magnéticos, tendo como representação química $\mathrm{MFe}_{2} \mathrm{O}_{4}$, onde $\mathrm{M}$ são cátions divalentes tais como: $\mathrm{Mg}^{2+}, \mathrm{Fe}^{2+}, \mathrm{Co}^{2+}, \mathrm{Ni}^{2+}, \mathrm{Cu}^{2+}, \mathrm{Zn}^{2+}, \mathrm{Mn}^{2+}{ }^{24}$. São materiais do tipo inorgânico com ótimas propriedades magnéticas, elétricas e ópticas. A característica magnética é concedida graças a presença de elétrons desemparelhados no orbital 3d e distribuídos em números não equivalentes nos sítios octaédricos e tetraédricos ${ }^{45}$. As ferritas estudas no presente trabalho são do tipo espínelio, ou seja, sua estrutura cristalográfica é caracterizada por uma célula unitária com 32 átomos de oxigênio em um empacotamento cúbico compacto, gerando 64 interstícios de simetria tetraédrica e 32 sítios de simetria octaédrica. Tem fórmula genérica $\mathrm{AB}_{2} \mathrm{O}_{4}$, onde $\mathrm{A}$ são cátions divalentes localizados em sítios tetraédricos e $\mathrm{B}$ é o cátion de $\mathrm{Fe}^{3+}$ localizado em sítios octaédricos ${ }^{46}$, como demostrado na figura 5. A cristalografia de materiais tipo espínelio pode ser: espinélio normal, espinélio reverso e espinélio misto. No caso de existir apenas átomos de metal divalente (M) nos sítios tetraédricos e $\mathrm{Fe}^{+3}$ nos sítios 
octaédricos, a cristalografia é denominada de espinélio normal. Quando existe a presença de $\mathrm{Fe}^{+3}$ nos sítios tetraédricos e na metade dos octaédricos, e o metal divalente ocupa a outra metade dos octaédricos, a estrutura é classificada como espinélio inverso. A fórmula cristalográfica $\left[\left(\mathrm{M}_{1-\delta} \mathrm{Fe}_{\delta}\right)_{\mathrm{A}}\left(\mathrm{M}_{\delta} \mathrm{Fe}_{2-\delta}\right)_{\mathrm{B}}\right] \mathrm{O}_{4}$ expõe de maneira mais clara a relação da ocupação dos metais divalentes e ferro trivalete com a classificação cristalográfica tipo espinélio. A letra A representa os sítios tetraédricos e a B os octaédricos. Nessa equação $\delta$ é o parâmetro de ocupação dos íons metálicos, se o valor for igual à zero, o espinélio é normal e quando esse valor é unitário, o espinélio é inverso. A estrutura será classificada como mista se o valor do parâmetro de ocupação estiver entre $0<\delta<1$, característica bastante favorecida ao se trabalhar em escala nano.
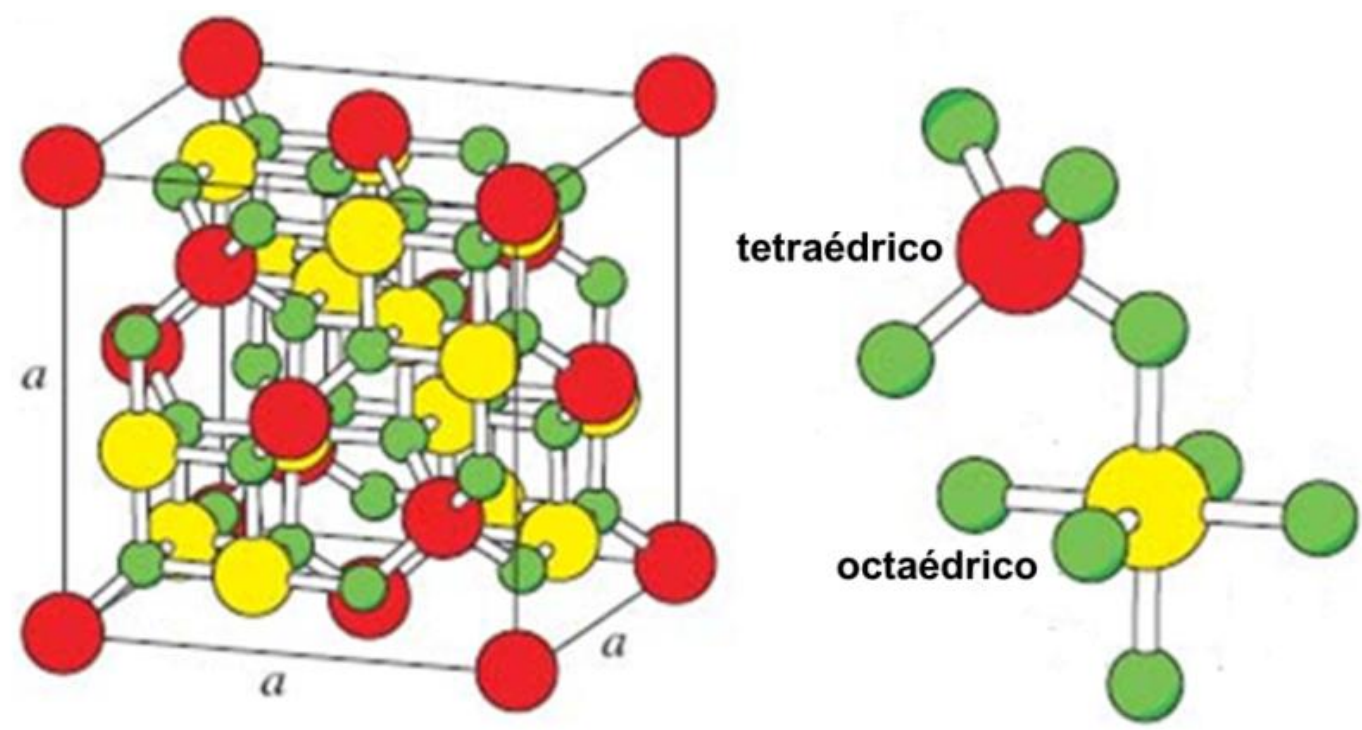

Figura 5- Representação de uma cela unitária da estrutura cristalográfica tipo espinélio em que as esferas verdes representam os átomos de oxigênio, as vermelhas os cátions dos sítios tetraédricos e as amarelas simbolizam os cátions nos sítios octaédricos.

As ferritas podem ser compostas por mais de um metal formando compostos do tipo $\mathrm{M}_{(1-\mathrm{x})}^{1} \mathrm{M}_{\mathrm{x}}^{2} \mathrm{Fe}_{2} \mathrm{O}_{4}$, em que $\mathrm{M}^{1}$ e $\mathrm{M}^{2}$ são diferentes metais $\left(\mathrm{Mn}^{2+}, \mathrm{Fe}^{2+}, \mathrm{Co}^{2+}, \mathrm{Ni}^{2+}, \mathrm{Cu}^{2+}\right.$, $\mathrm{Zn}^{2+}$ ). A ferrita de cobalto, por exemplo, é um material magnético “duro", apresenta alta 
coercividade e moderada saturação de magnetização, bem como estabilidade química e dureza mecânica ${ }^{47}$. Em comparação, os valores de magnetorestrição e acoplamento magnetomecanico são limitações característica desse material, restringindo sua aplicação em campos como o da biomedicina ${ }^{48}$. Sintetizar esses nanomateriais usando uma combinação de metais permite maior controle das propriedades magnéticas e magneto-ópticas ${ }^{49}$.

O magnetismo nas ferritas depende da resposta dos dipolos magnéticos individuais e da magnetização cooperativa em relação da presença ou ausência de um campo magnético aplicado. Podem ser classificadas como diamagnéticas, paramagnéticas, ferromagnéticas, ferrimagnéticas e antiferromagnéticas, conforme demonstrado na figura 6.

\begin{tabular}{|c|c|c|c|c|c|c|}
\hline $\begin{array}{l}\text { sem campo } \\
0000 \\
0000 \\
0000 \\
0000\end{array}$ & $\begin{array}{l}\text { com campo } \\
\theta \Theta \theta \Theta \\
\theta \theta \theta \theta \\
\theta \Theta \theta \Theta \\
\theta \oplus \Theta \theta\end{array}$ & $\begin{array}{l}\text { sem campo } \\
Q \otimes \bigotimes \varnothing \\
Q \varnothing \phi \varnothing \\
\phi \phi \phi \otimes \\
\otimes \otimes \phi \ominus\end{array}$ & 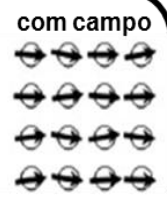 & $\begin{array}{l}\text { sem campo } \\
\theta \theta \theta \theta \\
\theta \theta \theta \theta \\
\theta \theta \theta \theta \\
\theta \theta \theta \theta\end{array}$ & 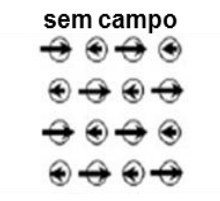 & $\begin{array}{l}\text { sem campo } \\
\theta \theta \theta \theta \\
\theta \theta \theta \theta \\
\theta \theta \theta \theta \\
\theta \theta \theta \theta\end{array}$ \\
\hline \multicolumn{2}{|c|}{ Diamagnetismo } & \multicolumn{2}{|c|}{ Paramagnetismo } & Ferromagnetismo & Ferrimagnetismo & Antiferromagnetisn \\
\hline
\end{tabular}

Figura 6 - Comportamento de dipolos magnéticos, simbolizados pelas setas escuras, na presença e ausência de campo magnético externo aplicado. Com base no alinhamento desses dipolos magnéticos, os materiais são classificados como diamagnético, paramagnético, ferromagnético, ferrimagnético e antiferromagnético.

Existem várias maneiras, físicas e químicas, de se sintetizar ferritas magnéticas, o que determina a forma mais adequada de preparo desses materiais é basicamente o objetivo de aplicação. Uma das rotas físicas bastante conhecida e utilizada é o de moagem de partículas micrométricas ${ }^{50}$. Em escala comercial o preparo de nanopartículas por meio de moagem é o mais comum, pois é de baixo custo e apresenta 
grande facilidade para processar a matéria prima em grande escala ${ }^{51}$. Outros métodos utilizados são a co-preciptação hidrotérmica e as técnicas de microemulsão. 
Objetivos 


\section{Objetivos}

\subsection{Objetivo Geral}

Elaborar nanossistema a base de nanopartículas de ferrita de cobalto e manganês, funcionalizadas com polidimetilsiloxano, para remoção de hidrocarbonetos em amostras de agua contaminadas.

\subsection{Objetivos específicos}

- Sintetizar, por coprecipitação hidrotérmica, nanopartículas de ferrita mista de cobalto e manganês, $\left(\mathrm{Mn}_{\mathrm{x}} \mathrm{Co}_{1-\mathrm{x}}\right) \mathrm{Fe}_{2} \mathrm{O}_{4}$ com x =0,5;

- Estabelecer parâmetros ótimos para a funcionalização das nanopartículas magnéticas com polidimetilsiloxano com terminação carboxílica (PDMSCOOH);

- Caracterizar as amostras sintetizadas por técnicas como difração de raios X, microscopia eletrônica de transmissão, espectroscopia moleculares FTIR, medidas de magnetização;

- Estudar, por meio de isotermas de adsorção, a eficiência da remoção de tolueno em amostras simuladas de água contaminada. 


\section{Materiais e}

Métodos 


\section{Materiais e Métodos}

A metodologia desse trabalho foi desenvolvida em 3 etapas: $i$ ) síntese química das nanopartículas magnéticas, ii) funcionalização das nanopartículas com o ligante PDMS e iii) testes de adsorção de tolueno em águas dopadas, com as nanopartículas magnéticas funcionalizadas. Para a caracterização das amostras sintetizadas e funcionalizadas, a principais técnicas utilizadas foram difração de raios $\mathrm{X}$ (DRX), microscopia eletrônica de transmissão (MET), espectroscopia de infravermelho (FTIR) e medidas de magnetização à temperatura ambiente (MAG). O experimento envolvendo a aplicação do material com amostras contaminadas foi realizado por meio da técnica de análise de carbono orgânico total (TOC). O quadro 3 relaciona, de forma simplificada, as principais técnicas utilizadas e as informações delas obtidas.

\begin{tabular}{|cl|}
\hline Técnica & \multicolumn{1}{c|}{ Função } \\
\hline DRX & Determinar a estrutura cristalina e diâmetro médio \\
& das nanopartículas magnéticas. Identificar a presença \\
& de PDMS nas amostras funcionalizadas. \\
\hline MET & Verificar a morfologia e polidispersão em tamanho \\
& das nanopartículas sintetizadas. \\
\hline FTIR & Verificar a efetividade de funcionalização das \\
& nanopartículas como PDMS. \\
\hline MAG & Investigar as diferenças de características de \\
& magnetização do material funcionalizado e não \\
& funcionalizado, bem como o teor de material \\
& magnético nessas amostras. \\
\hline
\end{tabular}

Quadro 3- Relação simplificada das técnicas de caracterização com suas respectivas funções. 


\subsection{Síntese das nanopartículas de ferrita de cobalto e manganês}

Para a síntese das ferritas mistas de cobalto e manganês utilizou-se $260 \mathrm{ml}$ de ferro trivalente $\left(\mathrm{Fe}^{3+}\right), 65 \mathrm{ml}$ de cobalto divalente $\left(\mathrm{Co}^{2+}\right)$ e $65 \mathrm{ml}$ de manganês divalente $\left(\mathrm{Mn}^{2+}\right)$, todos a 1,0 mol/L. Os reagentes foram misturados em um béquer (1) e aquecidos a $90^{\circ} \mathrm{C}$. Em seguida, preparou-se em outro béquer (2), uma solução de hidróxido de sódio $(\mathrm{NaOH})$ a 2,0 mol/L - utilizou-se 80 g do reagente em 2,0 L de água destilada. Após a ebulição dessa solução alcalina, o conteúdo do béquer 1 foi transferido para o béquer 2 e todo o material foi deixado sob agitação magnética e em ebulição por uma hora. Posteriormente, o precipitado obtido foi lavado 3 vezes com água destilada, separado por decantação magnética e lavado com $200 \mathrm{ml}$ de ácido nítrico $\left(\mathrm{HNO}_{3}\right)$ 1,0 mol/L, durante 30 minutos, sob agitação magnética.

Após descartar o sobrenadante ácido, a próxima etapa consistiu no acréscimo de $150 \mathrm{ml}$ de nitrato férrico $\left(\mathrm{Fe}\left(\mathrm{NO}_{3}\right)_{3}\right)$ a 1,0 $\mathrm{mol} / \mathrm{L}$ sob aquecimento até a ebulição $\left(\sim 95^{\circ} \mathrm{C}\right)$, durante 30 minutos. Por fim, o precipitado foi lavado 3 vezes com acetona $\left(\mathrm{C}_{3} \mathrm{H}_{6} \mathrm{O}\right)$ e disperso em aproximadamente $100 \mathrm{ml}$ de solução de água destilada. Cabe ressaltar, que em cada lavagem e na decantação magnética o sobrenadante foi descartado e a acetona restante foi evaporada ao final do processo. A figura 7 descreve sucintamente as etapas de síntese.

A amostra sintetizada foi utilizada como base para todos experimentos e o $\mathrm{pH}$ medido foi de 1,9. A concentração da amostra foi estimada após pesagem inicial de um volume/massa conhecidos do fluido e posterior pesagem dessa mesma alíquota, após evaporação quantitativa do solvente. 

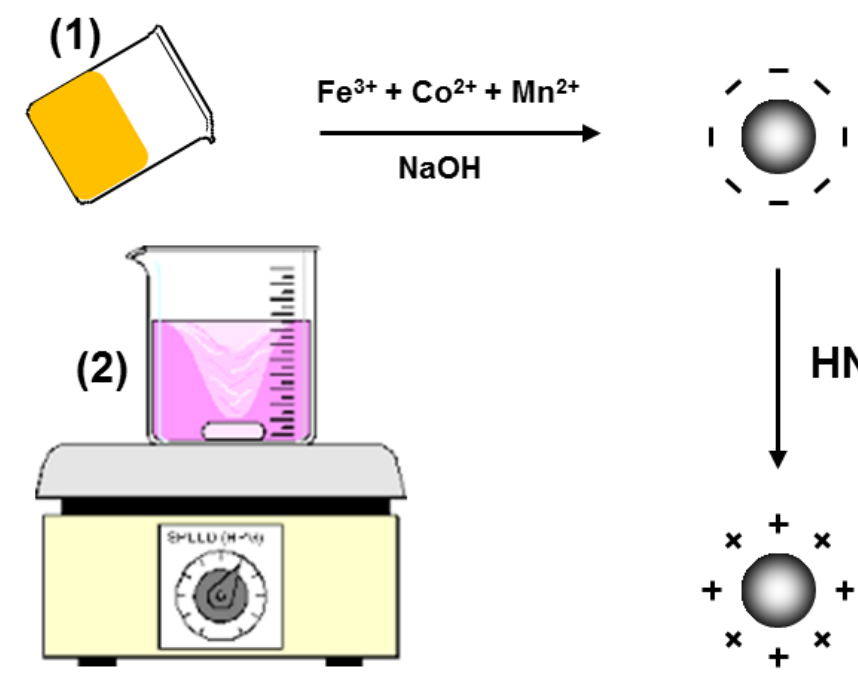

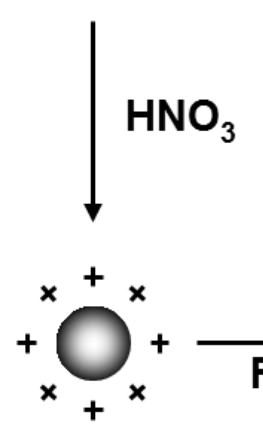

$100{ }^{\circ} \mathrm{C}$

\section{Ferrofluido}

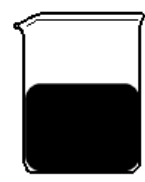

Acetona $\uparrow$

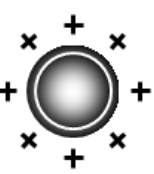

Figura 7 - Etapas realizadas no processo de síntese das ferritas de cobalto e manganês.

\subsection{Funcionalização das nanopartículas com PDMS}

Para funcionalização das nanopartículas, foi utilizado o reagente polidimetilsiloxano com terminação carboxílica (PDMSCOOH) - carboxy terminated polydimethylsiloxane da Polymersource ${ }^{\circledR}$ (vide ficha de segurança e caracterização em anexo). Na prática, foi utilizada uma proporção de $1,0 \mathrm{~mL}$ de ferrofluido anteriormente preparado e $500 \mu \mathrm{L}$ do reagente PDMSCOOH dissolvido em 5,0 mL de diclorometano. Após mistura, o solvente orgânico foi evaporado em evaporador rotativo e o pH da solução foi ajustado para 4,5. Após 24 h de interação por tombamento, o precipitado foi lavado três vezes com hexano e seco em temperatura ambiente. 


\subsection{Caracterização das amostras}

\subsubsection{Microscopia Eletrônica de Transmissão (MET)}

A técnica de microscopia eletrônica de transmissão serviu como ferramenta para averiguar a morfologia e determinar tamanho e polidispersão das nanopartículas. As amostras de foram diluídas em água ou hexano e depositadas em uma tela de cobre recoberta com carbono, secas por $24 \mathrm{~h}$ em dessecador. As amostras foram analisadas em um microscópio JEOL, modelo JEM-2100, no Instituto de Física da Universidade de Goiás. Os histogramas foram construídos a partir da contagem de cerca de 500 partículas e tratados com o programa ImageJ®.

Os histogramas obtidos foram ajustados pela função log-normal ${ }^{52}$, $P(d)=\frac{1}{\sqrt{2 \pi} s d} \exp \left[-\frac{1}{2 s^{2}}\left(\ln \frac{d}{d_{0}}\right)^{2}\right]$, fornecendo um diâmetro característico $d_{0}$ e a largura característica da polidispersão relacionada, $s$.

\subsubsection{Espectroscopia de Absorção no Infravermelho com Transformada de}

\section{Fourrier (FTIR)}

A espectroscopia de absorção por infravermelho com transformada em Fourrier (FTIR) foi utilizada para comprovar a interação dos grupos carboxilatos do ligante PDMSCOOH com a superfície das nanopartículas. Primeiramente foi feito a FTIR do PDMSCOOH, em seguida analisou-se as nanopartículas não-funcionalizadas e, por último, realizou-se a FTIR do ferrofluido funcionalizado com o PDMSCOOH.

A amostra de PDMSCOOH foi analisada no estado líquido, 
enquanto as nanopartículas funcionalizadas e não-funcionalizadas foram analisados em pastilhas de $\mathrm{KBr}$. Para as análises foi utilizado um espectrofotômetro Bruker, modelo Vertex-70, com resolução de $2 \mathrm{~cm}^{-1}$, via análise média de 32 scans, em modo de transmissão. Os espectros de infravermelho, para todas as amostras, foram obtidos na região de $4000-400 \mathrm{~cm}^{-1}$.

\subsubsection{Difração de raios X (DRX)}

A técnica de difração de raios $X$, muito utilizada para identificar a estrutura cristalina de sólidos, permite determinar características como a simetria cristalina, parâmetros de rede, distâncias interplanares, defeitos estruturais etc. Essa técnica só é possível porque o comprimento de onda utilizado é da mesma ordem de grandeza que a distância entre os átomos. A relação entre o ângulo de difração medido $(\theta)$, o comprimento de onda utilizado $(\lambda)$ e as distâncias interplanares $\left(\mathrm{d}_{\mathrm{hkl}}\right)$ da estrutura cristalina é dada pela Lei de Bragg $n \lambda=2 d_{h k l} \operatorname{sen} \theta$, em que n é a ordem de interferência. Uma vez calculados os valores das distâncias interplanares e de posse das respectivas intensidades relativas, estes são comparados aos valores das tabelas ASTM (American Society for Testing Materials). Dessa maneira, se consegue indexar os picos característicos associados às famílias de planos reticulares (hkl) da estrutura cristalina. No caso das ferritas do tipo espinélio (estruturas de simetria cúbica) a relação entre a distância inter-reticular e os índices de Miller é dada pela eq. $d_{h k l}=\frac{a}{\sqrt{h^{2}+k^{2}+l^{2}}}$.

Com o difratograma indexado é possível determinar o parâmetro de malha cúbico (a) que deve ser comparado com o valor de referência das fichas ASTM para confirmar a estrutura cristalina obtida no processo de síntese. Além disso, no caso de amostras policristalinas, é possível estimar a dimensão característica das partículas, 
utilizando-se o formalismo de Scherrer, $D_{R X}=\frac{0,9 \lambda}{B \cos \theta}$, em que B é a largura à meia altura do pico de maior intensidade, registrado no difratograma. Para análise por DRX, as amostras foram lavadas com acetona e secas em estufa a $45^{\circ} \mathrm{C}$. O pó obtido foi triturado e finamente pulverizado com auxílio de um graal de ágata e prensados em um porta-amostras de vidro. Em seguida foram analisadas em um difratômetro Miniflex 600, Rigaku, com detecção rápida DTex, operando a 40 kV, 30 mA e radiação $\mathrm{Cu}-K \alpha$, selecionada com um monocromador de grafite. As condições de varredura foram de 20 a $70^{\circ}$, com um passo de $0,02^{\circ}$ e velocidade de $5 \%$ min.

\subsubsection{Medidas de Magnetização}

A Magnetometria de Amostra Vibrante, ou VSM (Vibrating Sample Magnetometer) foi desenvolvida por Foner em 1955 e é atualmente uma das técnicas mais utilizadas, não só por ser relativamente sensível (sensibilidade da ordem de $10^{-5}$ emu), mas também por seu funcionamento simples e baixo custo de manutenção. A técnica fornece informações sobre as propriedades magnéticas da amostra por meio da curva de histerese, e se baseia na obtenção de magnetização por indução ${ }^{53}$ O VSM consiste em uma haste rígida fixa a um vibrador (um alto-falante). A amostra deve ser colocada na outra extremidade da haste e posicionada entre dois eletroímãs e um conjunto de bobinas detectoras. Para se obter o sinal da magnetização, faz-se vibrar a amostra perpendicularmente ao campo aplicado que, ao oscilar, produz uma variação do fluxo de campo magnético local, gerando uma corrente induzida alternada nas bobinas detectoras posicionadas em torno da amostra. Desta forma é registrada a intensidade do momento magnético da amostra. 
Sem prévia diluição, as amostras de FMs magnéticos e os pós dessas amostras, obtidos por lavagem com acetona e secagem em estufa, foram analisados em magnetômetro VSM, em uma faixa de campo magnético, de -18 kOe a +18 kOe, a $25^{\circ} \mathrm{C}$.

\subsection{Testes de adsorção}

Para o estudo da adsorção, o tolueno foi escolhido como representante dos BTEX, em um primeiro momento. As amostras de água contendo esse hidrocarboneto foram preparadas da seguinte maneira: uma solução estoque de tolueno de $250 \mathrm{mg} / \mathrm{L}$ foi preparada pela mistura de $290,7 \mu \mathrm{L}$ de tolueno com água, em um balão volumétrico de 1 L. Em seguida, foram preparadas alíquotas de 20,0 $\mathrm{mL}$ pela diluição da amostra anteriormente preparada, em uma faixa de concentração de 10,0 a 250,0 mg/L. Para tal, alíquotas de 20, mL de água foram colocadas em recipientes adequados (vials) e, em seguida, retirou-se de cada frasco a mesma quantidade de água (em volume) que foi adicionada da solução de tolueno concentrada, de acordo com as concentrações requeridas $(10,0 ; 20,0 ; 30,0 ; 50,0 ; 75,0 ; 100,0 ; 150,0 ; 200,0 ;$ e 250,0 mg/L). Os fracos foram hermeticamente fechados, com septo, para que não houvesse nenhuma perda por evaporação. Amostras idênticas foram preparadas, adicionando-se 5,0 mg das NP's funcionalizadas à mistura e o sistema ficou sob tombamento por $12 \mathrm{~h}$. Todas as amostras foram acondicionadas em refrigerador, a $4{ }^{\circ} \mathrm{C}$, até o momento da análise.

Para determinação do teor de tolueno, parte da amostra foi retirada do frasco, com auxílio de uma seringa de vidro, e analisada em um equipamento TOC-5000A da Shimadzu. No caso das amostras contendo as NP's, essa análise foi feita após cuidadosa separação dos sólidos com auxílio de um ímã. 
O Analisador de Carbono Orgânico Total opera por um princípio de combustão catalítica, em que a amostra é queimada em um tubo onde está contido o catalisador, aquecido a temperaturas $>650{ }^{\circ} \mathrm{C}$, sob arraste de um gás, como o ar sintético, de alta pureza.

Esse analisador mede a concentração de carbono total (TC) e de carbono inorgânico (IC) na amostra. Para o TC, após injeção e combustão da amostra, os gases formados passam por um desumidificador e filtro de halogênio para, então, serem levados até uma célula de medida de infravermelho não-dispersivo, onde o $\mathrm{CO}_{2}$ é, então, detectado e convertido em TC. Na quantificação de carbono inorgânico (IC), a amostra é acidificada com ácido fosfórico para que todo o carbono inorgânico proveniente (principalmente de carbonatos e/ou bicarbonatos) ser convertido em $\mathrm{CO}_{2}$ e quantificado. A partir da diferença entre TC e IC, a quantidade de carbono orgânico pode ser estimada. O quadro 4 mostra as condições experimentais utilizadas e as características das curvas de calibração obtidas para a análise feita nesse trabalho.

Condições experimentais: O Analisador de Carbono Orgânico Total foi operado com um catalisador de sensibilidade normal, erro máximo de $2 \%$ em cada uma das determinações, e limite de quantificação de $1,0 \mathrm{mgC} / \mathrm{L}$.

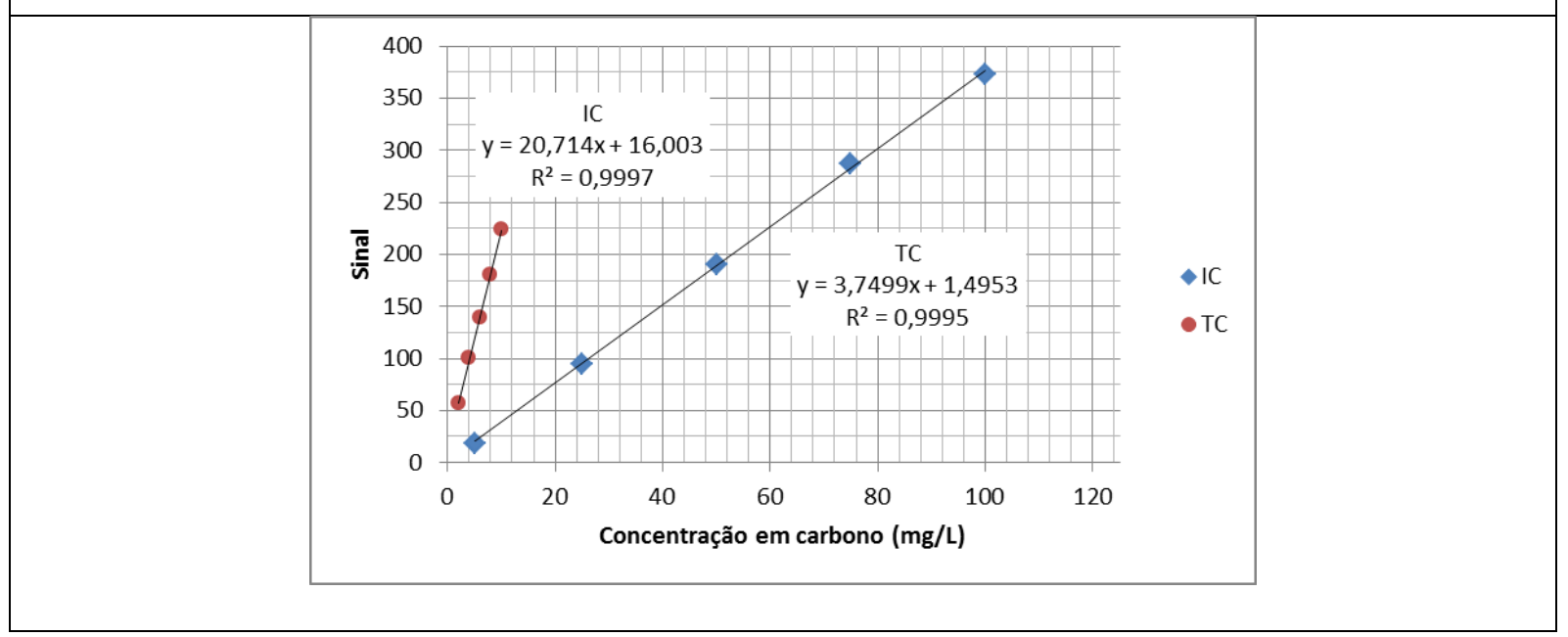

Quadro 4- Curvas de calibração para carbono total (TC) e carbono inorgânico (IC). 


\section{Resultados e}

discussão 


\section{Resultados}

\subsection{Síntese das nanopartículas magnéticas}

Ao fim do procedimento de síntese descrito em materiais e métodos, obteve-se um precipitado escuro que foi separado com o auxílio de um imã. A reação que representa a formação do material pode ser expressa na equação abaixo, na qual $0 \leq x \leq 1$ (em mol). Nesse caso, espera-se $x=0,5 \mathrm{~mol}$, que foi o valor de partida para os reagentes, no início da síntese.

$$
x \mathrm{Co}^{2+}+(1-x) \mathrm{Mn}^{2+}+2 \mathrm{Fe}^{2+}+8 \mathrm{OH}^{-} \rightarrow \mathrm{Mn}_{1-x} \mathrm{Co}_{x} \mathrm{Fe}_{2} \mathrm{O}_{4}+4 \mathrm{H}_{2} \mathrm{O}
$$

Posteriormente, com o intuito de retirar o excesso de íons da base utilizada na síntese, como o $\mathrm{Na}^{+}$que é um íon polarizante e que pode induzir a coagulação dos coloides ${ }^{54}$, o material foi lavado 3 vezes com água. O ideal é que os contra-íons, em um sol, sejam mais volumosos, como é o caso dos ânions nitrato $\left(\mathrm{NO}_{3}{ }^{-}\right)$, perclorato $\left(\mathrm{ClO}_{4}{ }^{-}\right)$ e do cátion tetrametilamônio $\left(\mathrm{H}_{3} \mathrm{C}\right) \mathrm{N}^{+}$, muito utilizados na preparação de fluidos magnéticos ${ }^{55}$.

No caso de óxidos de ferro, mesmo sem funcionalizar a superfície das nanopartículas e com o devido controle da força iônica do meio, é possível preparar sóis estáveis em meio ácido ou alcalino - em meio neutro isso não é possível - apenas com o controle do pH. No modelo trabalhado, os fluidos magnéticos são chamados de iônicos ou com dupla camada elétrica e a estabilidade coloidal ocorre devido às forças de repulsão eletrostática entre as nanopartículas. Em trabalhos anteriores, por meio de medidas eletroquímicas simultâneas ${ }^{56}$, verificou-se que esse sistema coloidal magnético comporta-se como uma mistura complexa de ácidos: um forte, relacionado aos íons 
hidrônio do seio da dispersão; e um ácido fraco diprótico associado à superfície da nanopartícula. A dupla camada elétrica é obtida por meio de reações de aquation em que as sucessivas hidrólises permitem o estabelecimento dos equilíbrios a seguir, de acordo com o modelo de dois pK's (Two-pK Model), conforme reações a seguir:

$$
\begin{aligned}
& \equiv \mathrm{MOH}_{2}^{+}+\mathrm{H}_{2} \mathrm{O} \stackrel{\mathrm{pK}_{1}}{\rightleftharpoons}=\mathrm{MOH}+\mathrm{H}_{3} \mathrm{O}_{(\mathrm{aq})}, \\
& \equiv \mathrm{MH}+\mathrm{H}_{2} \mathrm{O} \stackrel{\mathrm{pK}_{2}}{\rightleftharpoons}=\mathrm{MO}^{-}+\mathrm{H}_{3} \mathrm{O}_{(\mathrm{aq})}^{+}
\end{aligned}
$$

Esses equilíbrios conduzem a três tipos de sítios superficiais, cuja maioria é composta por $\equiv \mathrm{MOH}_{2}{ }^{+}$em meio fortemente ácido, um anfotérico $\equiv \mathrm{MOH}$ em região de neutralidade e outro $\equiv M O^{-}$em meio fortemente básico. $p K_{1}$ e $p K_{2}$ são as constantes termodinâmicas relativas aos equilíbrios e dependem, fundamentalmente, da natureza da superfície das partículas $(p K=-\log K)$, conforme ilustrado na figura 8 . Dessa forma, a densidade de carga superficial $\left(\sigma_{0}\right)$ resulta de um complexo mecanismo de transferência de prótons entre a superfície e o seio da dispersão. Nesse modelo, a densidade superficial de carga das nanopartículas é dada por $\sigma_{0}(p H)=\frac{F}{A} V\left(\frac{10^{-2 p H}-10^{-\left(p K_{1}+p K_{2}\right)}}{10^{-2 p H}+10^{-\left(p H+p K_{1}\right)}+10^{-\left(p K_{1}+p K_{2}\right)}}\right) C_{T}$ em que $F$ é a constante de Faraday, $V$ é o volume da dispersão, $A$ é a área total das nanopartículas e $C_{\mathrm{T}}$ é a concentração total dos sítios superficiais. Efetuando-se medidas potenciométricas e condutimétricas simultâneas às amostras, pode-se determinar a concentração total e as frações molares dos sítios superficiais da partícula. Com isso, é possível expressar o valor de saturação da densidade superficial de carga. 


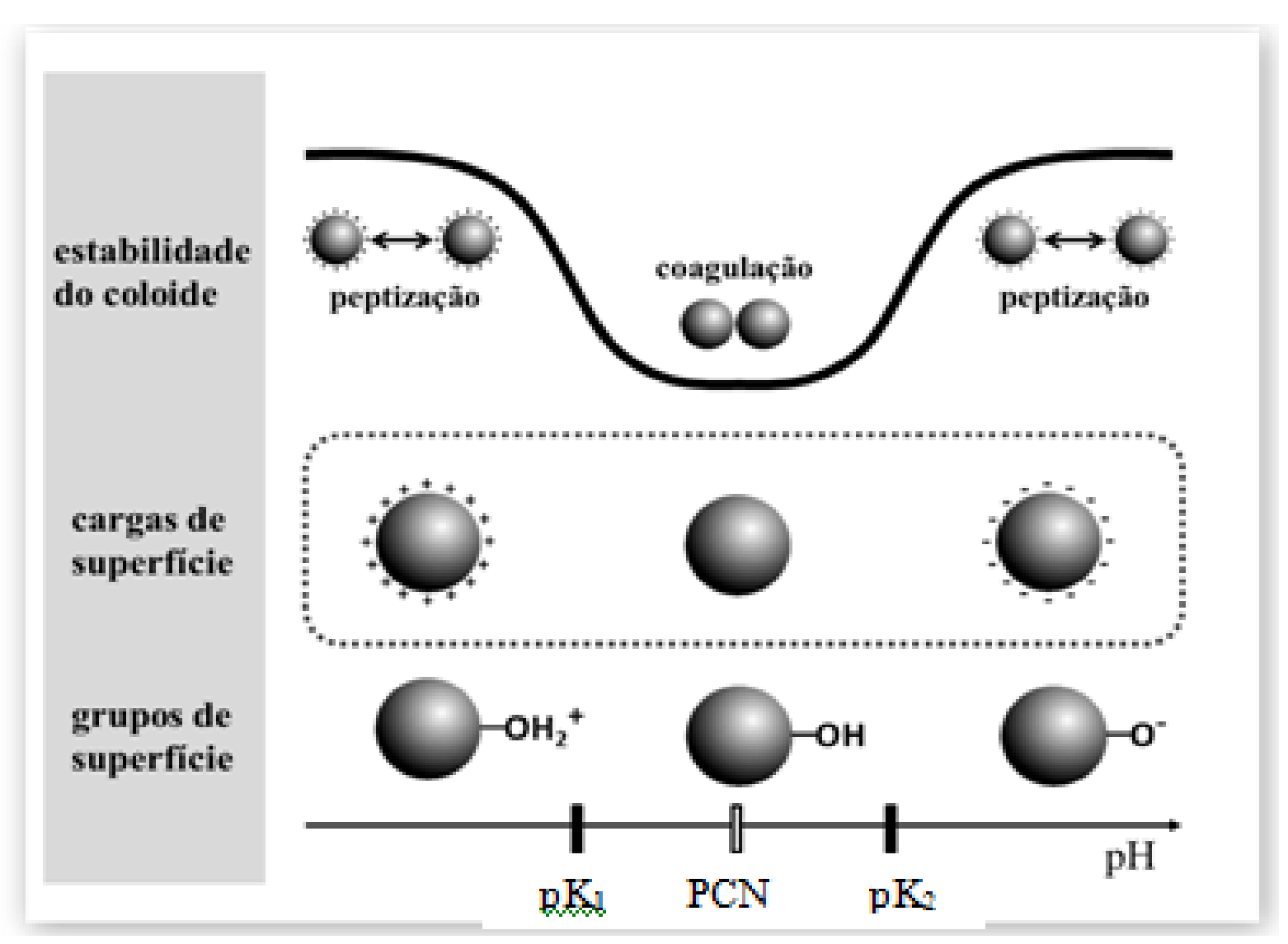

Figura 8- Diagrama esquemático representando a estabilidade coloidal, as cargas de superfície e os grupos associados a essas cargas, em função do $\mathrm{pH}$. $\mathrm{p} K_{\mathrm{a} 1}$ e $\mathrm{p} K_{\mathrm{a} 1}$ representam os valores das constantes de dissociação ácida dos grupos de superfície e IEP representa o ponto isoelétrico, em $\mathrm{pH} \sim 7$ para as NPMs aqui estudadas.

Para o preparo do ferrofluido, de capa nula, em meio aquoso estudado no trabalho, o meio escolhido foi ácido, pois nessa faixa de $\mathrm{pH}$ a superfície das nanopartículas se encontram positivamente carregada e coloides estáveis podem ser obtidos por longos períodos.

Assim, as nanopartículas foram lavadas com ácido nítrico para baixar o $\mathrm{pH}$ e estabelecer $\mathrm{O} \mathrm{NO}_{3}{ }^{-}$como contra-íon, realizando-se, em seguida, um tratamento hidrotérmico na presença de nitrato férrico, com o intuito de aumentar a estabilidade físico-química do material, evitando a dissolução das nanopartículas em meio ácido por meio do depósito uma camada de um óxido/hidróxido de ferro a superfície das mesmas 
57 . Dessa forma, após extração do excesso de $\mathrm{Fe}\left(\mathrm{NO}_{3}\right)_{3}$ não reagido, pela lavagem sucessiva do precipitado com acetona, evaporação do resíduo desse solvente e reposição de água, um sol estável de concentração $20 \%$ em massa, a pH 2, pôde ser obtido. A amostra, cujas características macroscópicas estão mostradas na figura 9, foi então armazenada e utilizada para caracterização e preparação das amostras funcionalizadas e para testes de adsorção.

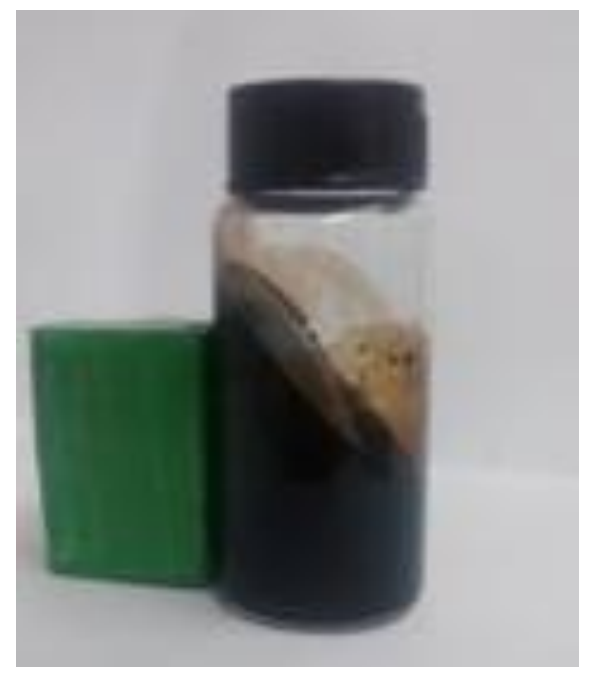

Figura 9 - Ferrofluido a base de ferritas de cobre e manganês. O magnetismo do material é claramente perceptível pela ação do imã.

Com a finalidade de investigar a estrutura cristalográfica e o diâmetro cristalino das nanopartículas, uma amostra do fluido magnético foi seca em estufa a $50{ }^{\circ} \mathrm{C}$ e uma análise por difratometria de raios $\mathrm{X}$ foi realizada no pó obtido. Os dados dessa análise estão plotados na forma de um difratograma, da intensidade difratada versus o ângulo de difração, na figura 10. Após comparação com padrões ASTM $^{58}$, foi possível identificar uma única fase cristalina que corresponde à estrutura do tipo espinélio - os principais picos de difração estão devidamente indexados no gráfico. 


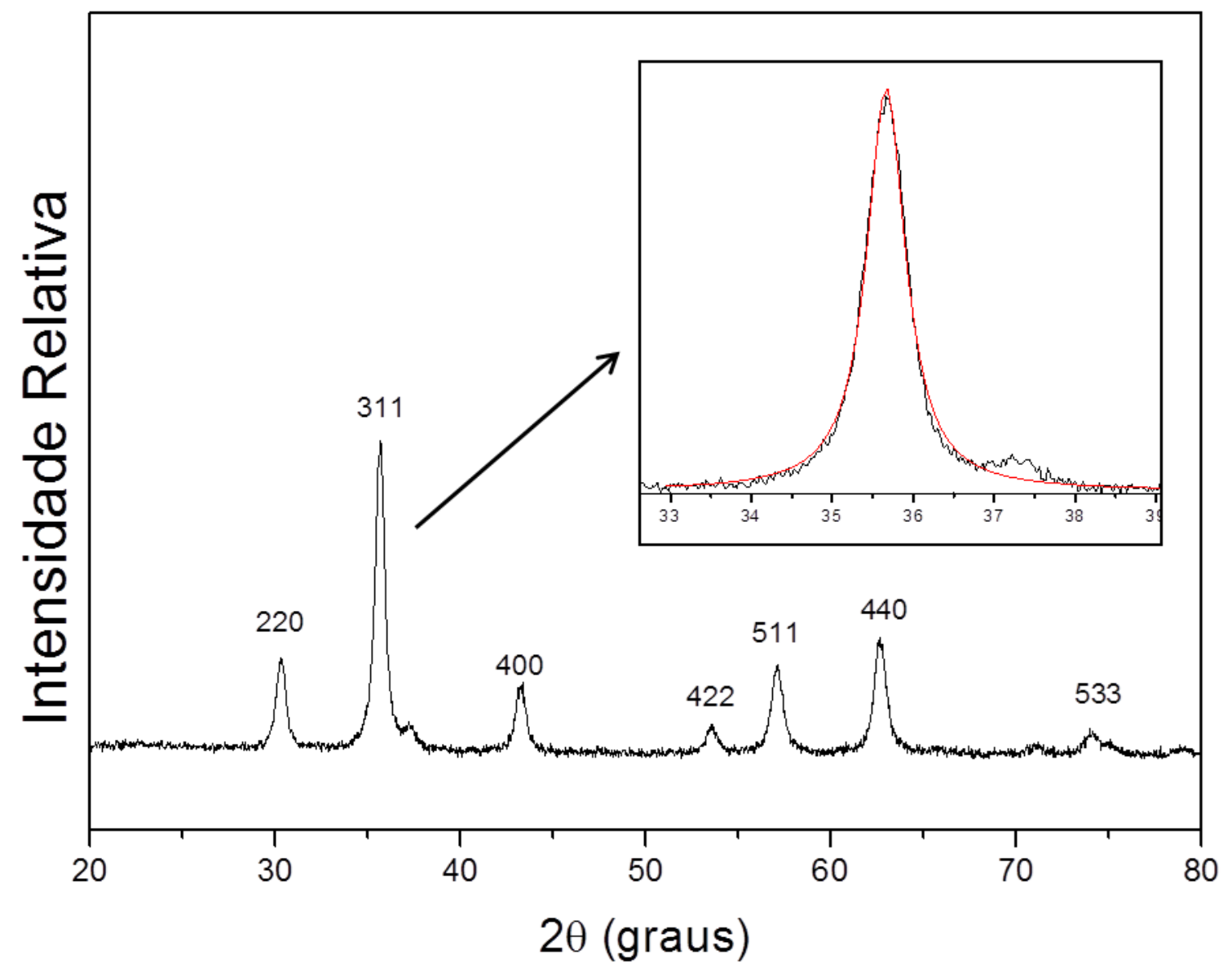

Figura 10 - Difratograma de raios x das nanoparticulas sintetizadas. A ampliação é do pico 311.

O cálculo do parâmetro de malha, que levou a um valor de 8,411 , intermediário aos valores para as ferritas de cobalto $(8,392 \AA)$ e manganês $(8,499 \AA)$ puras, indica o caráter misto da estrutura sintetizada nesse trabalho.

Além disso, o diâmetro médio estimado a partir do ajuste do principal pico de difração (311) - vide gráfico inserido na figura $X X$ - e por meio da equação de Scherrer, foi de $13,5 \mathrm{~nm}$. 
Para verificar morfologia e padrão em tamanho das nanopartículas, uma alíquota da amostra sintetizada foi diluída em água e depositada em uma tela de cobre recoberta por carbono para análise por microscopia eletrônica de transmissão. Na imagem típica obtida para essa amostra (figura 11), é possível notar que as nanopartículas são polidispersas em tamanho e têm formato aproximadamente esférico.

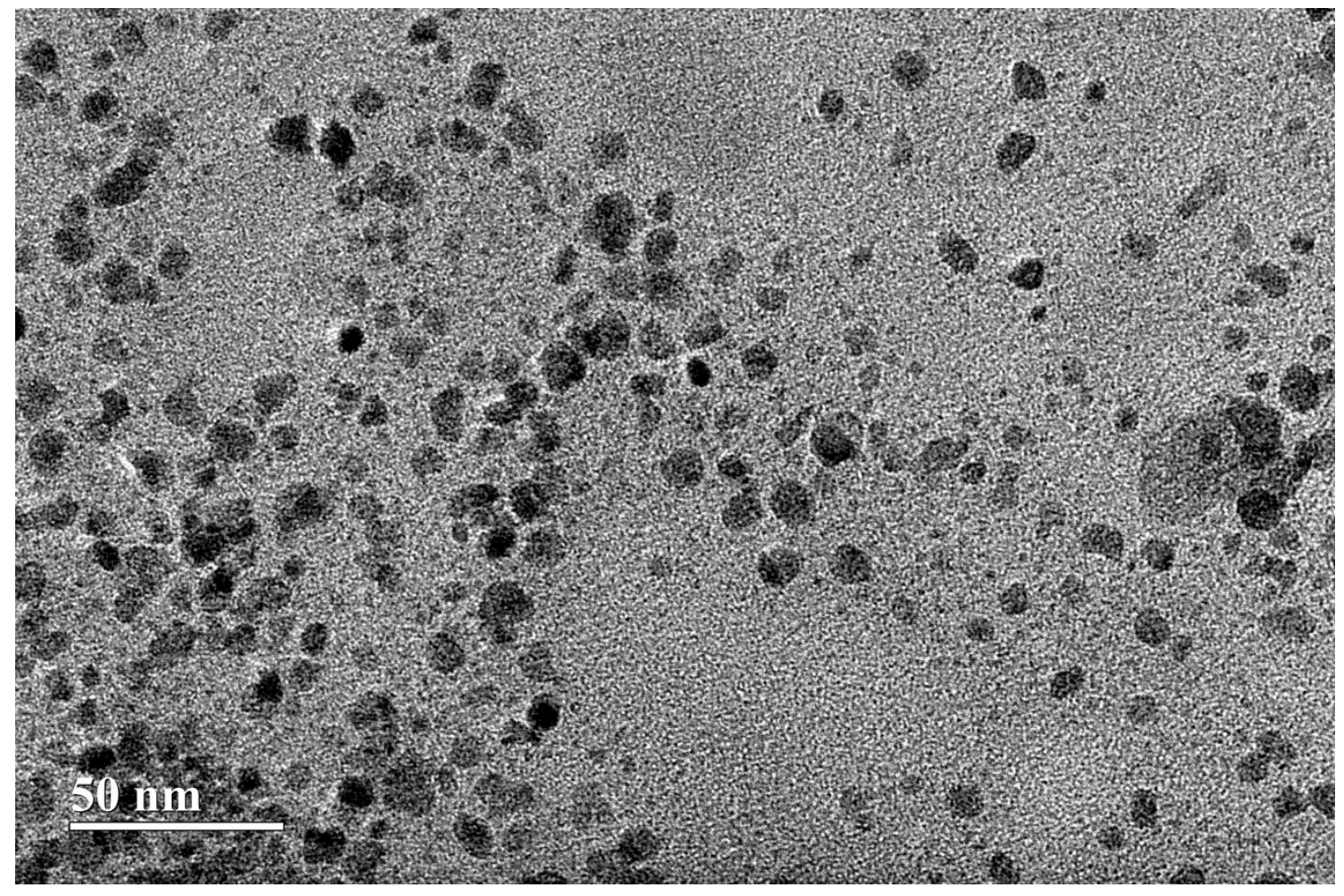

Figura 11 - Imagem da microscopia eletrônica de transmissão da amostra de nanoparticulas de ferritas de cobalto e manganês não funcionalizadas.

Além disso, a partir da imagem de TEM de alta resolução mostrada na figura 12, foi possível identificar uma distância interplanar de 2,48 ̊̊, que é uma distância interplanar típica e correspondente à distância entre dois planos (311) adjacentes na estrutura espinélio. 


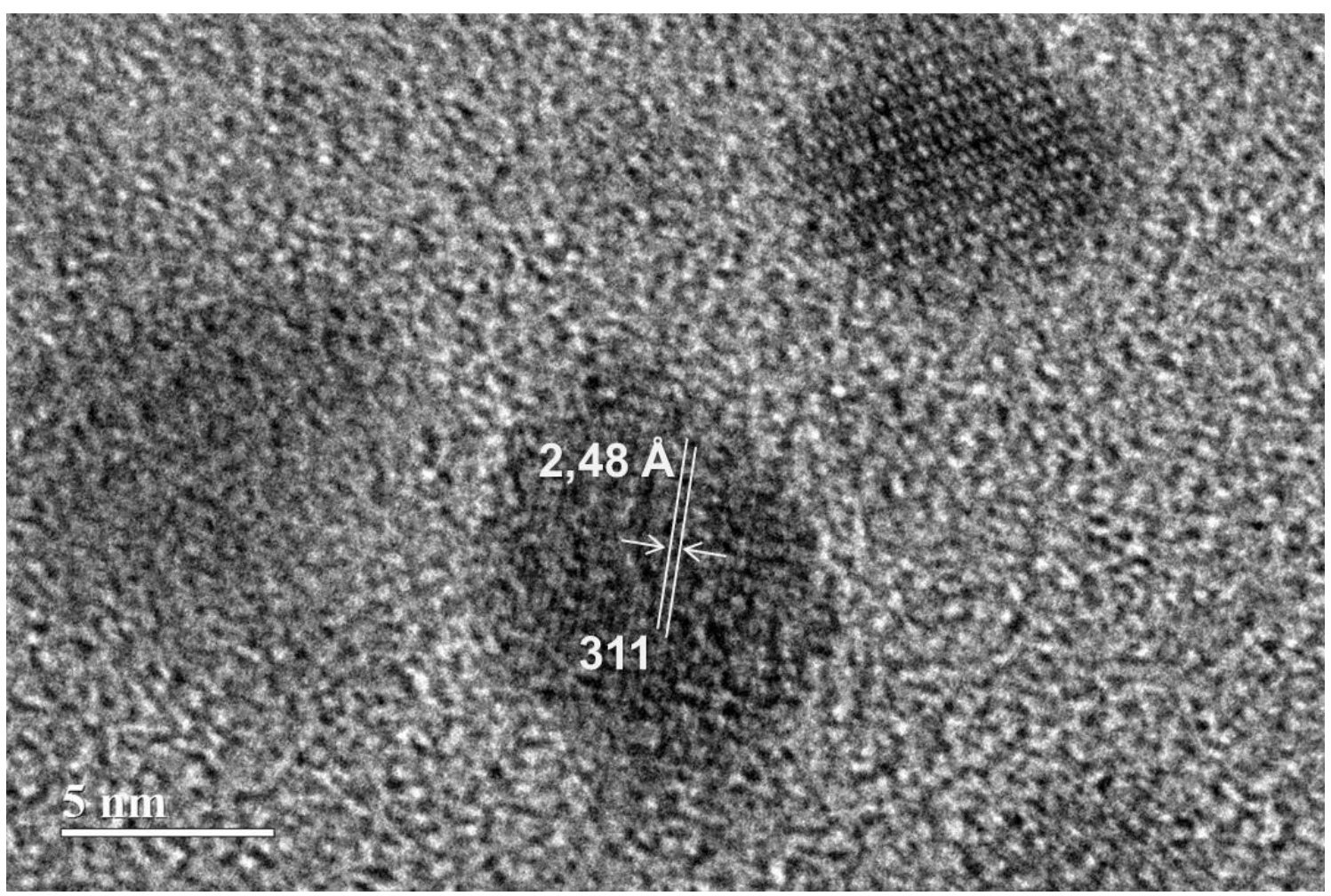

Figura 12 - Imagem em alta resolução das nanoparticulas a base de ferrita de cobalto e manganês por microscopia eletrônica de transmissão.

Para estimar a polidispersão, um histograma foi obtido a partir da contagem de centenas de partículas - figura 13. Após ajuste matemático com uma função log-normal, foi obtida uma polidispersão de 0,21 e um diâmetro característico de 12,9 nm. É possível observar que o diâmetro determinado por TEM é um pouco menor que o diâmetro obtido por DRX. Isso se deve ao fato de que o diâmetro obtido por DRX não leva em conta, eventuais partes pouco cristalinas das nanopartículas e que, na contagem de partículas para plotagem do histograma, por TEM, partículas maiores em agregados não são consideradas. 


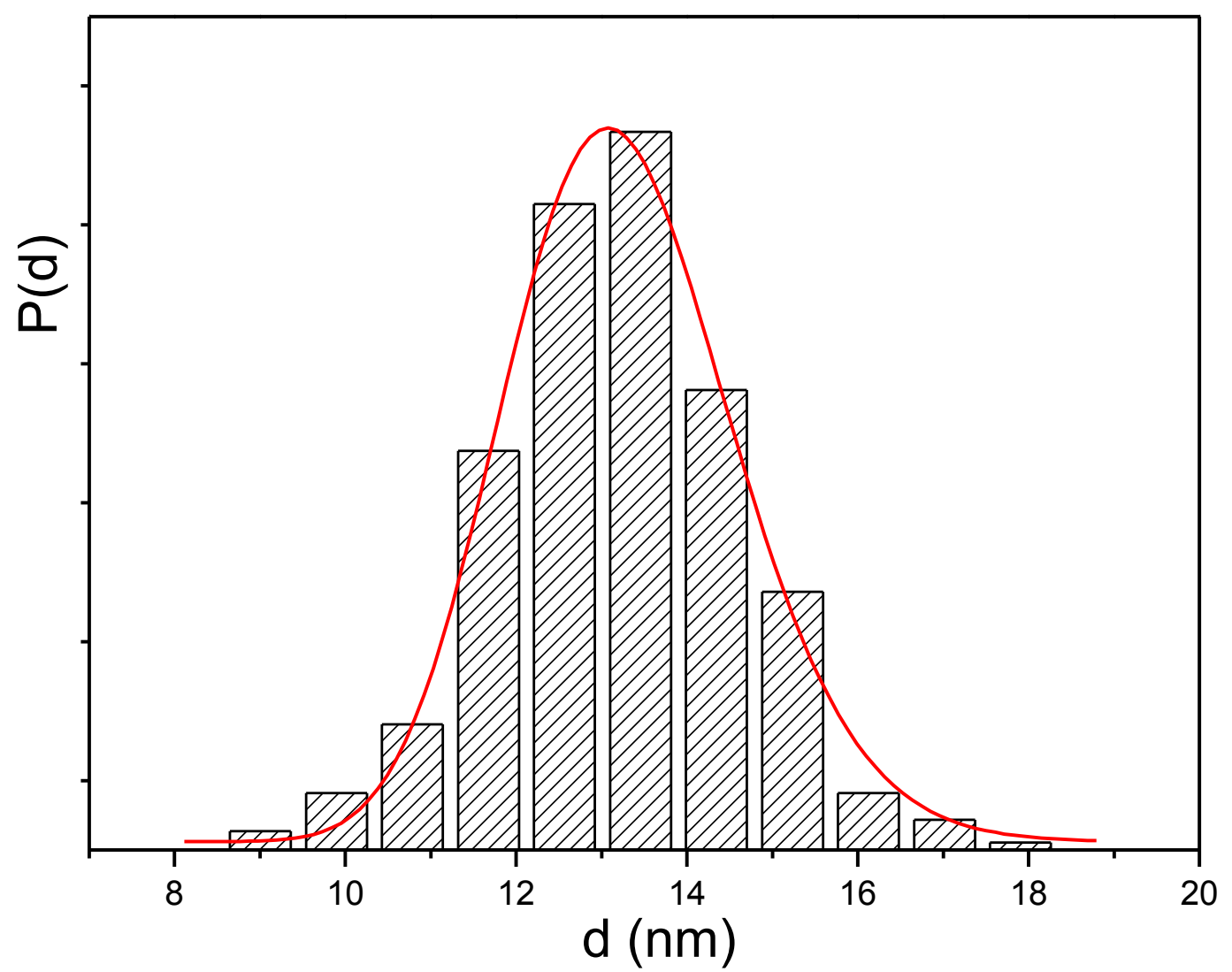

Figura 13 - Histograma das NPM de ferrita cobalto e manganês não funcionalizadas.

\subsection{Funcionalização das nanopartículas magnéticas com PDMSCOOH}

Uma vez que as nanopartículas sintetizadas não apresentavam afinidade química com as moléculas apolares a serem adsorvidas, para tornar possível a remoção desses contaminantes da água foi necessário funcionalizá-las com um polímero adequado. Levando-se em consideração que o PDMS é conhecidamente um polímero com grande afinidade com as moléculas a serem adsorvidas, os BTEX, e estudos anteriores que mostraram sua eficiência para a funcionalização de nanopartículas de magnetita ${ }^{51}$, esse mesmo polímero foi utilizado no presente trabalho para modificar as nanopartículas de 
ferritas de cobalto e manganês mistas. No modelo de funcionalização escolhido, foi selecionada a estratégia de complexação dos metais superficiais da nanopartículas pelo ligante, por meio de grupamentos carboxilatos $\left(-\mathrm{COO}^{-}\right)$. De fato, a complexação de ligantes via carboxilato é uma técnica que permite conferir hidrofobicidade (pela adsorção de oleato, por exemplo) ou hidrofilicidade, mesmo em soluções fisiológicas (adsorção de citrato, por exemplo) ${ }^{59}$. Nessa funcionalização, os grupamentos carboxilato coordenam-se à superfície da partícula, enquanto a cadeia da molécula do ligante, segundo suas características, modificam a nanopartículas em relação ao seu caráter de afinidade aos diferentes solventes ou meios.

Dessa forma, foi escolhida uma estrutura de polidimetilsiloxano modificada com um grupamento carboxilato, cuja estrutura está mostrada na figura 14 e abreviada como PDMSCOOH nesse trabalho. É possível notar que esse polímero apresenta uma longa cadeia hidrofóbica e, na extremidade, um grupamento carboxila. De acordo com os dados do fornecedor (vide anexo), o peso molecular médio numérico e o peso molecular médio ponderal são, respectivamente iguais a 10.000 e 10.900 .

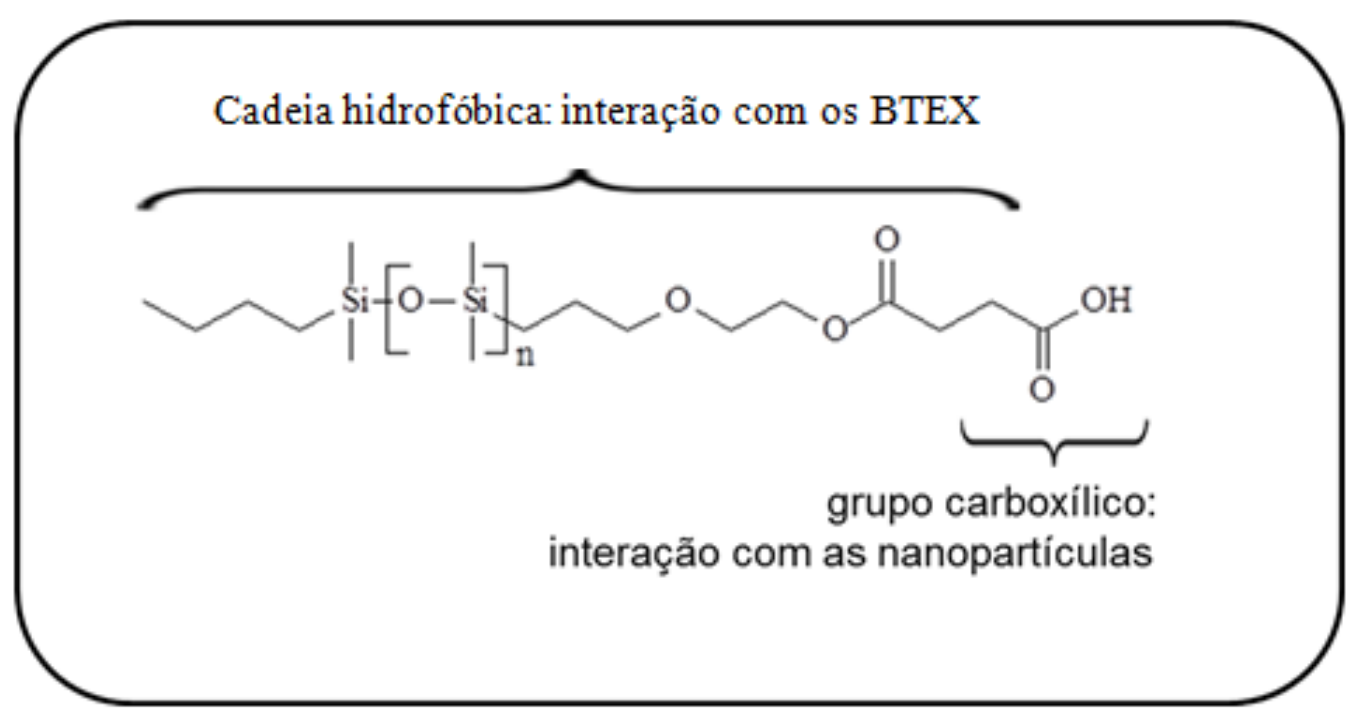

Figura 14- Representação da molécula de PDMS. 
Para otimizar a ligação do PDMSCOOH à superfície das NP, é necessário levar em conta as propriedades químicas desses dois sistemas: por um lado, a superfície das NP's é rica em metais de transição (especialmente o ferro), mas que estão coordenados com espécies provenientes de um equilíbrio com o meio aquoso, conforme discutido no seção 5.1. Por outro lado, as moléculas do PDMSCOOH apresentam um grupo funcional ácido carboxílico que, na sua forma desprotonada, complexa facilmente aos metais da superfície das NP. No entanto, o status desses dois sistemas é fortemente alterado conforme o pH do meio. De fato, o PDMSCOOH sofre dissociação ácida em meio aquoso, segundo o equilíbrio $\mathrm{PDMSCOOH}+\mathrm{H}_{2} \mathrm{O} \rightarrow \mathrm{PDMSCOO}^{-}+\mathrm{H}_{3} \mathrm{O}^{+}$, com valor de $\mathrm{p} K_{\mathrm{a}}$ característico e dependente do tipo e tamanho de cadeia.

A figura 15 ilustra uma situação ideal para a complexação dos metais superficiais pela molécula do PDMSCOOH. A forma desprotonada do ligante $\left(\mathrm{PDMSCOO}^{-}\right)$, negativamente carregada, tem grande afinidade pelas NP positivamente carregadas $\left(\equiv \mathrm{MOH}_{2}{ }^{+}\right)$. De fato, o grupo carboxilato, que é um doador de elétrons, substitui o grupo $-\mathrm{OH}_{2}{ }^{+}$ligado ao sítio superficial, estabelecendo um complexo estável com a partícula.
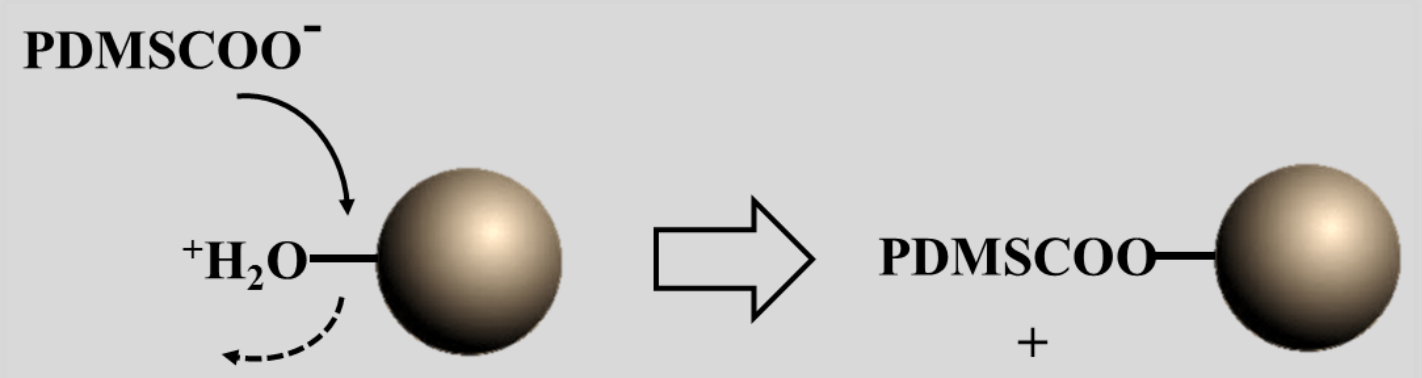

$\mathrm{H}_{2} \mathrm{O}$

Figura 15 - Representação da complexação da superfície das NPMs pelo ligante PDMSCOOH)via carboxilato. 
Dessa forma, a partir da equação de Henderson-Hasselbalch e das constantes termodinâmicas relativas aos equilíbrios de transferência de prótons, é possível caracterizar tanto a especiação do ligante, quanto da superfície das nanopartículas, para determinar a faixa ótima de $\mathrm{pH}$ em que há maior eficiência de funcionalização. Nesse diagrama (figura 16), os percentuais de cada espécie estão traçados em função do $\mathrm{pH}^{60}$. As curvas pontilhada, tracejada e tracejada-pontilhada em vermelho representam, respectivamente, as frações das espécies $\equiv \mathrm{MOH}_{2}{ }^{+}, \equiv \mathrm{MOH}$ e $\equiv \mathrm{MO}^{-}$das NP's. A curva em azul representa a variação da espécie PDMSCOO`.

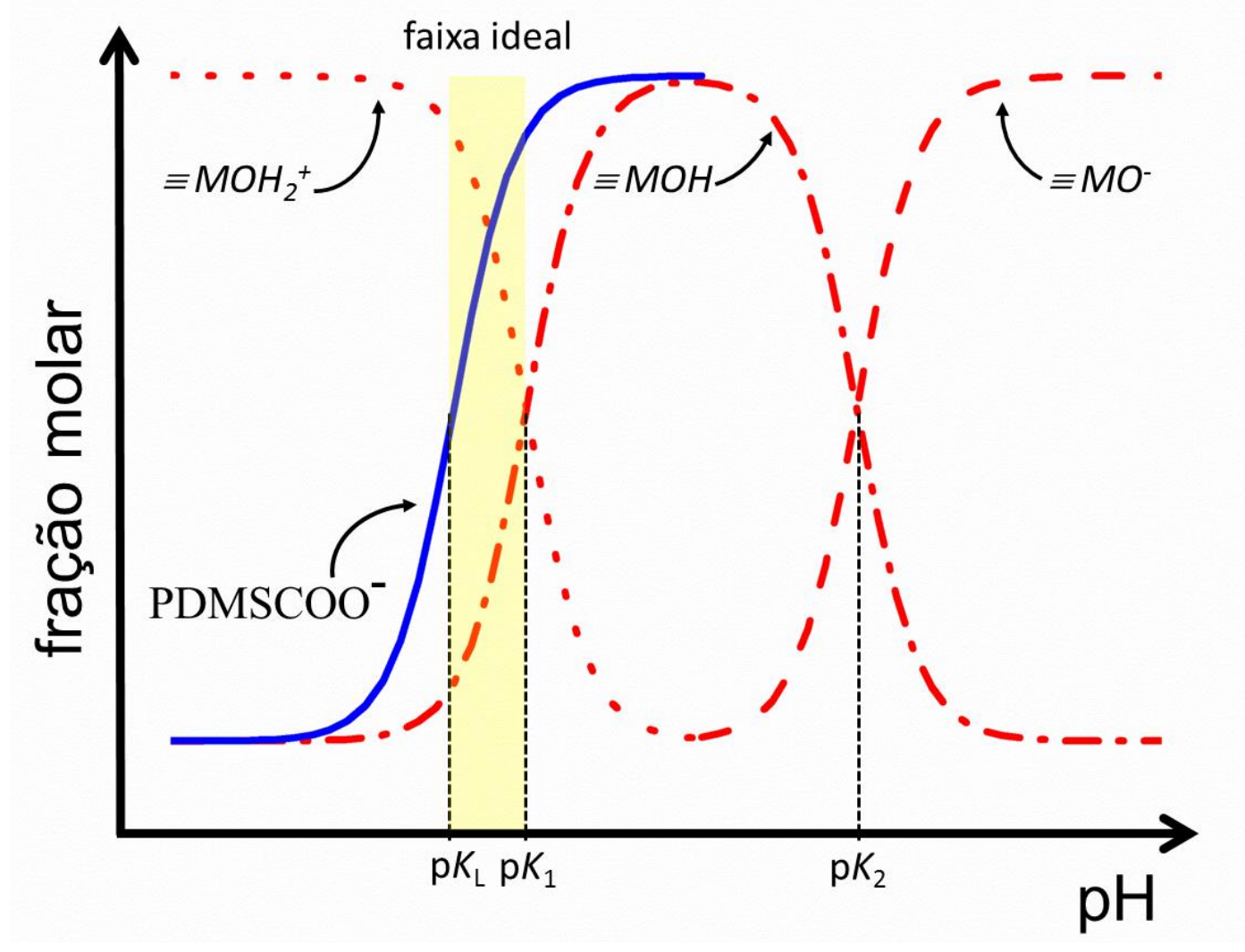

Figura 16 - Diagramas de especiação da superfície das NPMs (em vermelho) e dos ligantes (em azul). As constantes de dissociação ácidas das NPs $\left(\mathrm{p} K_{\mathrm{a} 1}\right.$ e $\left.\mathrm{p} K_{\mathrm{a} 2}\right)$ e do ligante $\left(\mathrm{p} K_{\mathrm{L}}\right)$, assim como o $\mathrm{pH}$ ideal de complexação, estão indicados na figura. 
Em pHs que vão de neutros a alcalinos, apesar do PDMSCOOH estar desprotonado e apto a se complexar, as nanopartículas estão descarregadas ou apresentam cargas negativas em sua superfície, o que diminui a eficiência de ligação dessas moléculas com o sólido. A interação será mais efetiva, conforme mostrado na figura 19, em uma faixa ótima de $\mathrm{pH}$, em que as NP estão maximamente na forma $\equiv \mathrm{MOH}_{2}{ }^{+}$e o ligante na forma $\mathrm{PDMSCOO}^{-}$, situada entre a constante de dissociação do PDMSCOOH $\left(\mathrm{p} K_{\mathrm{L}}\right)$ e o $\mathrm{p} K_{1}$, relativo à primeira dissociação da superfície da NP.

A partir desse raciocínio, considerando-se que para esse tipo de ferrita o $\mathrm{p} K_{1}$ médio gira em tordo de 5 e levando-se em conta que o valor de $\mathrm{p} K_{\mathrm{L}}$ é aproximadamente 4, determinou-se um pH ótimo para acoplamento igual a 4,5. Assim, após ter o pH alterado para essa região, a mistura de NP's e PDMSCOOH ficou reagindo por $24 \mathrm{~h}$ por tombamento e foram lavadas com hexano a fim de se retirar o excesso de ligante não acoplados ao sólido.

Em um primeiro momento, os difratogramas de raios $\mathrm{X}$ das nanopartículas nãofuncionalizadas e funcionalizadas, plotados na figura 17 , foram comparados a fim de se verificar a presença das diferentes fases na amostra funcionalizada.

No difratograma das NP's não-funcionalizadas, os principais picos de difração do óxido magnético estão indexados e no difratograma das NP's funcionalizadas, onde é possível verificar picos extras aos do espinélio, as fases inorgânica e orgânica (PMDMSCOOH) coexistem. De fato, devido à baixa cristalinidade do polímero e sua pequena concentração em face à ferrita, os picos em cerca de $23^{\circ}$ e $33^{\circ}$ foram destacados, e estão em concordância com padrões observados em literatura ${ }^{61}$. 


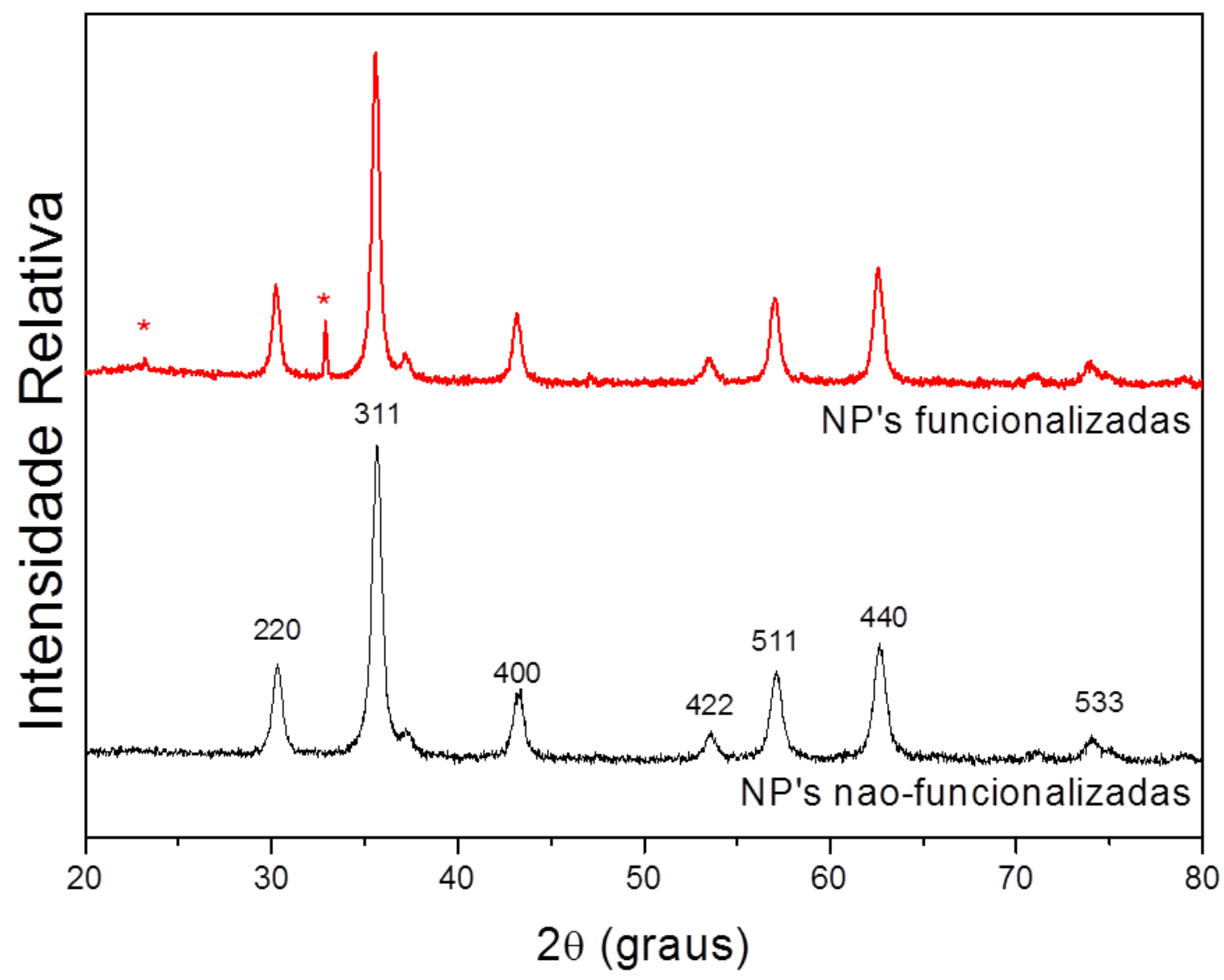

Figura 17 - Difratograma de raios x das nanoparticulas funcionalizadas (vermelho) e não funcionalizadas (preto). Os picos entre $23^{\circ}$ e $33^{\circ}$ provavelmente é de estruturas cristalizadas durante o processo de preparo das amostras para a realização da técnica de difração de raio $\mathrm{x}$.

Uma vez que a técnica de DRX não confirma a interação entre as fases orgânica e inorgânica, mas somente indica a coexistência das mesmas, para se verificar a efetividade da funcionalização, análises por espectroscopia de absorção no infravermelho foram realizadas. Os espectros de FTIR registrados entre $4000 \mathrm{~cm}^{-1}$ e 400 $\mathrm{cm}^{-1}$ para o PDMSCOOH, nanopartículas não-funcionalizadas e funcionalizadas estão plotados na figura 18. Para as NP's não funcionalizadas, as vibrações de estiramento características de $\mathrm{O}-\mathrm{H}$ são observadas na região de $3300 \mathrm{~cm}^{-1}$ e a banda de absorção presente em cerca de $1630 \mathrm{~cm}^{-1}$ pode ser atribuída à flexão das moléculas de água adsorvida na superfície das nanopartículas. As bandas de absorção presentes em 
frequências menores que $600 \mathrm{~cm}^{-1}$ são comumente atribuídas como características das vibrações de estiramento desse tipo de óxido metálico. Para o PDMSCOOH, as bandas mais características são as situadas na região de 1265 e em torno de $1400 \mathrm{~cm}^{-1}$, que podem ser atribuídas a difração da ligação $\mathrm{C}-\mathrm{H}$ simétricos e assimétricos, respectivamente, nos grupos $\mathrm{Si}_{-} \mathrm{CH}_{3}{ }^{62}$. Com respeito à funcionalidade da moléculas, em $1712 \mathrm{~cm}^{-1}$, aparece uma banda característica do estiramento $\mathrm{C}=\mathrm{O}$ do grupamento $\mathrm{COOH}$ (forma ácida) desse ligante. É interessante notar que, no espectro das NP's funcionalizadas, essa banda referente ao ácido, em $1712 \mathrm{~cm}^{-1}$, é praticamente suprimida, dando lugar as bandas em aproximadamente $1608 \mathrm{~cm}^{-1}$ e a um ombro em cerca de 1451 $\mathrm{cm}^{-1}$. Esses perfis podem ser atribuídos aos estiramentos assimétricos e simétricos da carboxila (forma ionizada, $\mathrm{COO}^{-}$), na superfície da ferrita, possivelmente, por meio de uma complexação bidentada, já que a diferença de frequências entre os estiramentos assimétricos e simétricos da carboxila observado $\left(\sim 160 \mathrm{~cm}^{-1}\right)$ é maior que essa diferença para o ligante ionizado, mas não adsorvido às nanopartículas (tipicamente $140-150 \mathrm{~cm}^{1}$ ) 62. Além disso, é possível notar que as nanopartículas funcionalizadas apresentam as características espectrais tanto do óxido, quanto do ligante. 


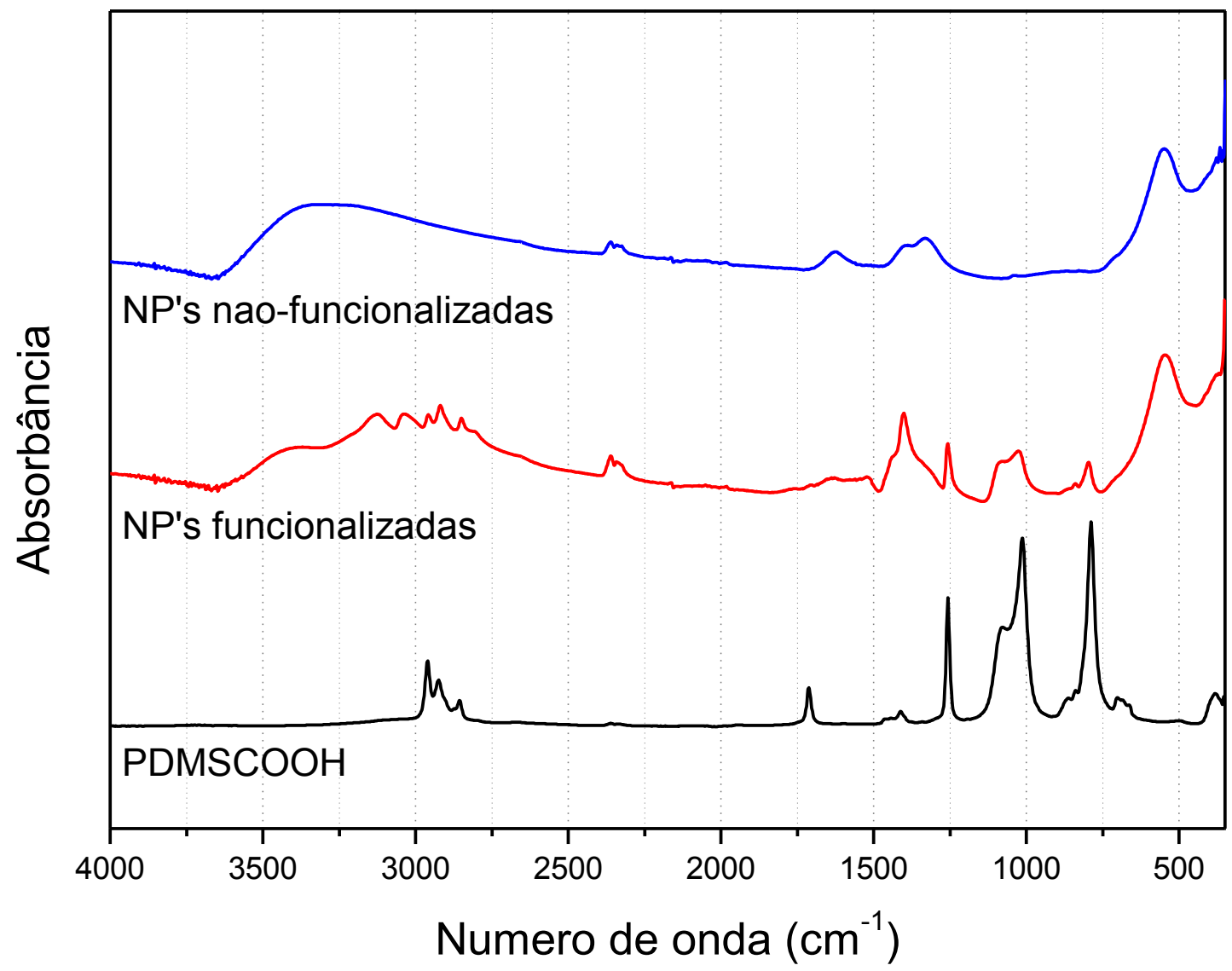

Figura 18 - Espectros de FTIR das amostras analisadas: Ferrofluido puro, ferrofluido funcionalizado e PDMS. Os picos ajudam a caracterizar a composição química dos materiais e colaboram com a análise para concluir se o PDMS se aderiu, ou não, a superfície das nanoparticulas.

As nanopartículas funcionalizadas também foram analisadas por microscopia eletrônica de transmissão e a imagem obtida, após dispersão da amostra magnética com PDMSCOOH em hexano e secagem em tela de cobre adequada, está mostrada na figura 19. Como é mais facilmente visualizado na ampliação, é possível notar que as nanopartículas magnéticas estão imersas em um material de baixa densidade, supostamente o PDMSCOOH. Entretanto, como houve aglomeração das NP's no processo de preparação da amostra, não é possível concluir se as NP's estão 
individualmente recobertas por PDMSCOOH ou se há aglomerados de sólidos recobertos por esse polímero.

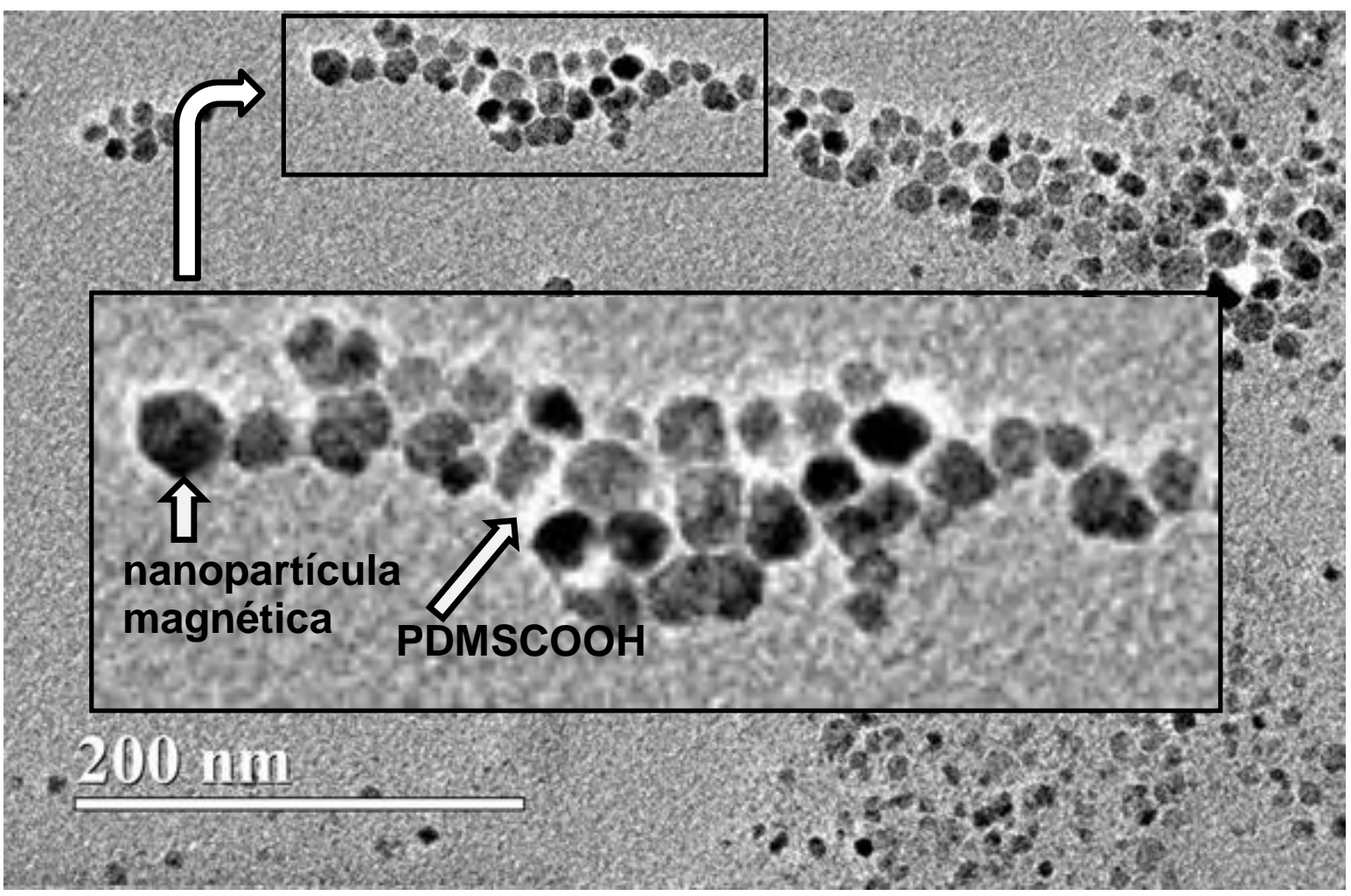

Figura 19 - Imagem de MET das nanopartículas funcionalizadas.

Para avaliar as propriedades magnéticas das nanopartículas, assim como as mudanças aportadas pela funcionalização, medidas de magnetização foram efetuadas nas NP's não-funcionalizadas e funcionalizadas, a temperatura ambiente, em um ciclo de histerese, para um campo magnético aplicado de -17 kOe a 17 kOe. Dessa maneira, a figura 20 mostra as curvas de magnetização (M), à temperatura ambiente, em função do campo magnético aplicado $(\mathrm{H})$.

Para as NP's não-funcionalizadas, representadas pela curva em azul, é possível observar que a magnetização aumenta à medida que o campo magnético se intensifica, 
até atingir magnetização de saturação em cerca de $62 \mathrm{emu} / \mathrm{g}$, valor típico para nanopartículas de tamanho similar ferrita de cobalto ou ferrita de manganês obtidas pelo mesmo tipo de síntese ${ }^{57}$. Além disso, quando o campo é diminuído e invertido para fechar o ciclo de histerese, é possível notar que há magnetização remanente e campo coercitivo listados na tabela 1 , indicando que as partículas apresentam características ferromagnéticas.

\begin{tabular}{cccc}
\hline Amostra & Ms & Hc & Mr \\
& $(\mathbf{e m u} / \mathbf{g})$ & $(\mathbf{O e})$ & $(\mathbf{e m u} / \mathbf{g})$ \\
\hline não-funcionalizada & 62 & 200 & 11 \\
\hline funcionalizada & 55 & 380 & 16 \\
\hline
\end{tabular}

Tabela 1 - Parâmetros de magnetização para nanoparticulas funcionalizadas e não funcionalizadas.

Como se trata de uma ferrita mista é de se esperar que o sistema apresente características intermediárias das ferritas puras de cobalto e de manganês. Por exemplo, sabe-se que a ferrita de cobalto $\left(\mathrm{CoFe}_{2} \mathrm{O}_{4}\right)$ é um material magnético "duro", que tem sido estudado em detalhes devido à sua alta coercividade e moderada saturação de magnetização, assim como estabilidade química e dureza mecânica ${ }^{63}$.Entretanto, os altos valores de magnetorestrição e acoplamento magnetomecânico limitam a aplicação desses materiais em diversos campos, como o da biomedicina e separação magnética ${ }^{64}$ 

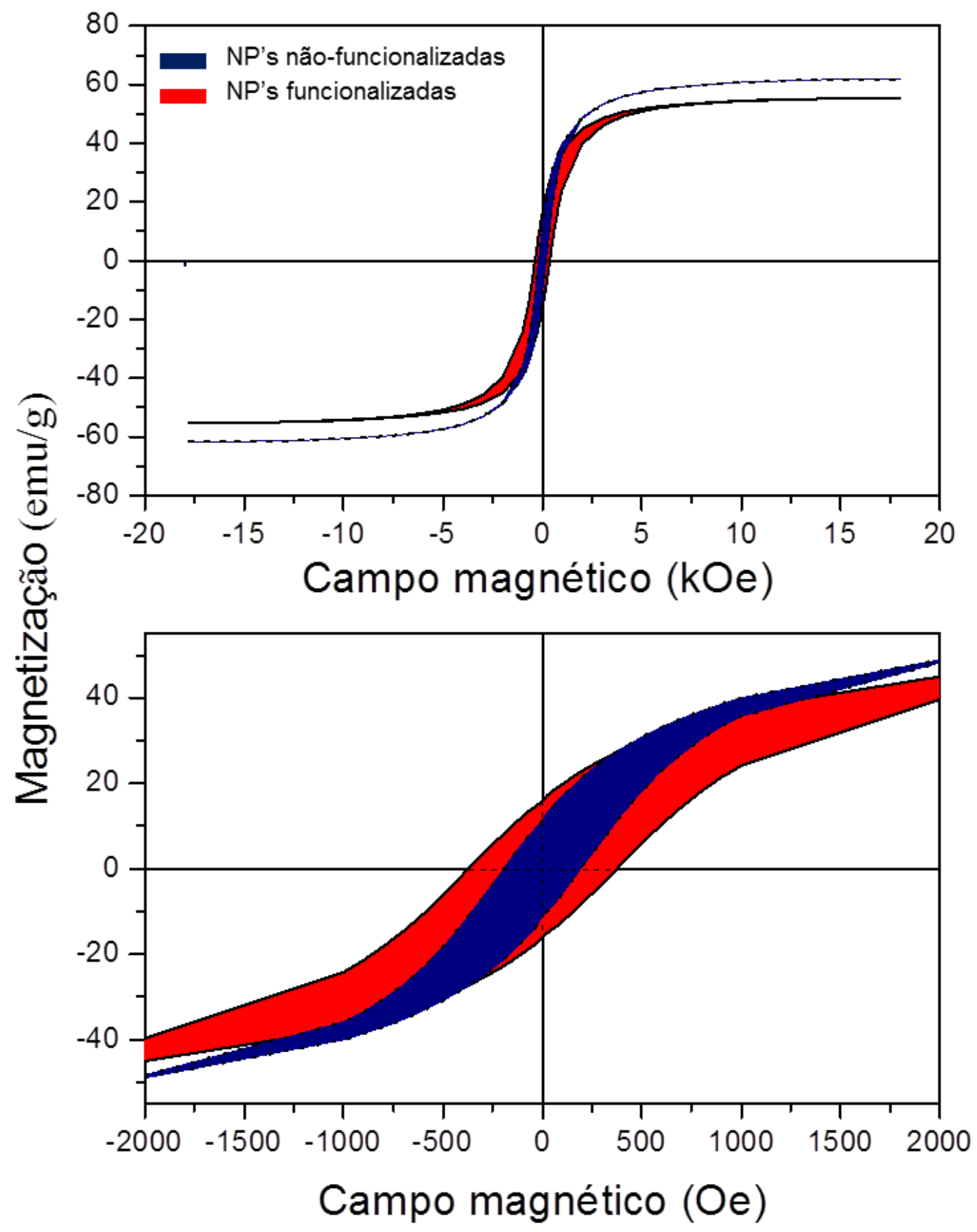

Figura 20 - Curva de magnetização versus campo magnético aplicado para as NPs não funcionalizadas. $\mathrm{O}$ gráfico em detalhe mostra a histerese. 
Porém, a substituição por outros elementos, como o manganês $\left(\mathrm{Mn}_{1-x} \mathrm{Co}_{x} \mathrm{Fe}_{2} \mathrm{O}_{4}\right)$, tem sido proposta para manipular essas restrições, permitindo maior controle das propriedades magnéticas e magneto-ópticas desses nanomateriais ${ }^{65}$.Por outro lado, a análise das características magnéticas desse materiais exige estudos mais aprofundados, já que nessa dimensão, há redistribuição catiônica ${ }^{66}$ e efeitos de superfície e de tamanho finito característicos da nanoescala ${ }^{67}$.

Para as nanopartículas magnéticas funcionalizadas, o perfil da curva de magnetização é o mesmo das não funcionalizadas, porém há diminuição da magnetização de saturação da amostra, principalmente pela incorporação do polímero não magnético ao núcleo magnético - após normalizar essa curva pela magnetização das nanopartículas não funcionalizadas, foi possível estimar que o "compósito" é formado por $11,3 \%$ em massa de PDMSCOOH sendo, o restante, a ferrita magnética. Além disso, conforme curva em vermelho na figura 20, após funcionalização, a área de histerese, assim como os valores de campo coercitivo e magnetização remanente, aumentam (tabela 1). Isso pode ser associado à interação entre o ligante PDMSCOOH e as NP's, mais especificamente ao desdobramento da energia do campo cristalino após coordenação do grupo $-\mathrm{COO}^{-}$do ligante à superfície das nanopartículas ${ }^{68}$.

Todos esses resultados corroboram para propor um modelo de nanomaterial em que as nanopartículas de ferrita de cobalto e manganês são funcionalizadas com as moléculas de $\mathrm{PDMSCOO}^{-}$, via complexação dos metais superficiais pelo grupo COOdo ligante, conforme ilustrado na figura 21. Dessa forma, devido às características do polímero da superfície, as NP's funcionalizadas adquirem uma característica hidrofóbica e, em especial, podem interagir bem com os BTEX. Para avaliar qualitativamente essa situação, em uma mistura contendo água e tolueno, foram adicionadas nanopartículas funcionalizadas. Após agitação e estabilização do sistema, é 
possível notar que as NP's se dispersaram na fase de tolueno, comprovando a boa interação entre o sólido e a fase orgânica.

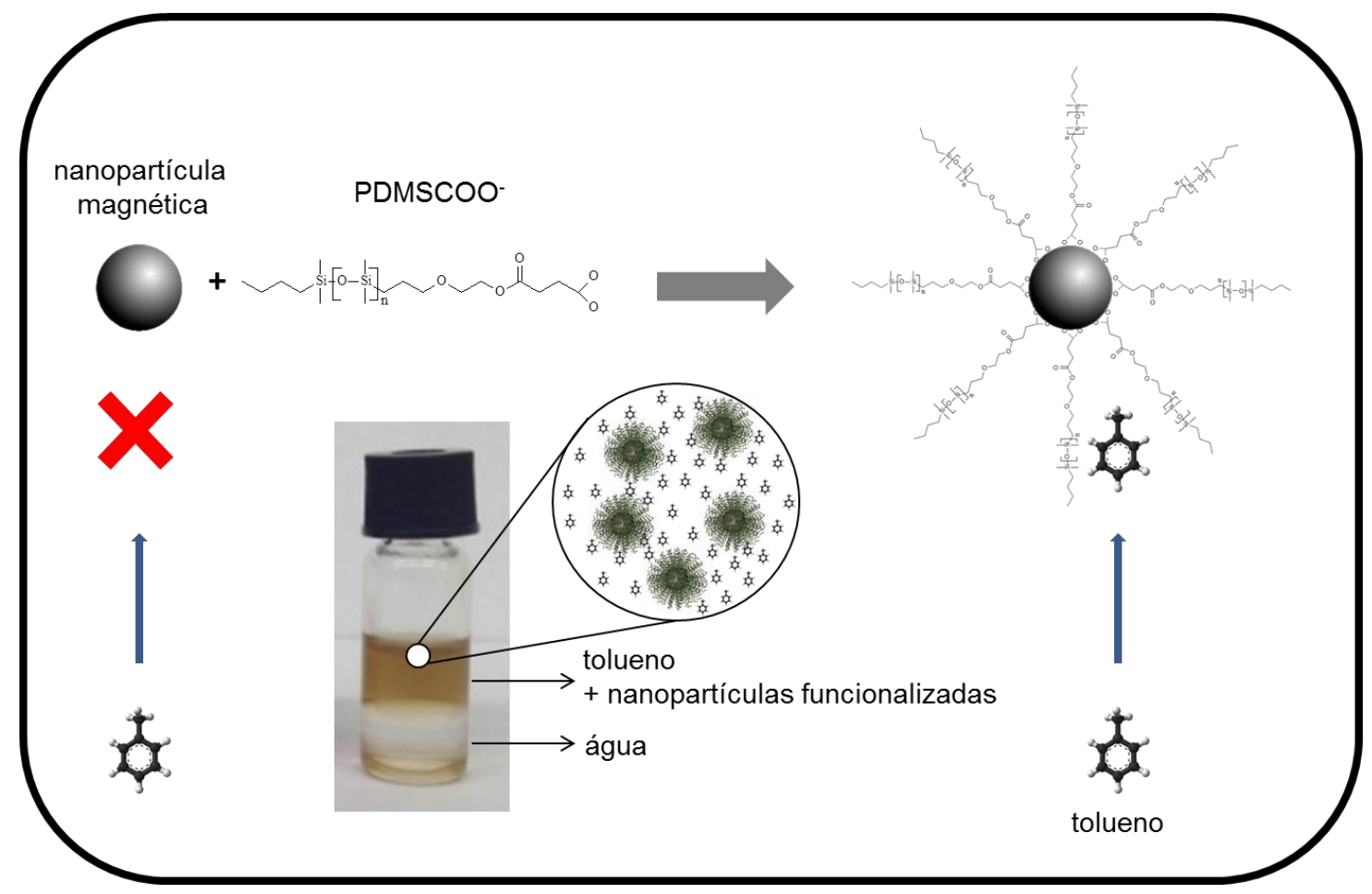

Figura 21 - Representação da interação do PDMS com a superfície das nanopartículas. No frasco contendo a amostra é possível perceber duas fases: tolueno + nanopartículas funcionalizadas e água. As características macroscópicas da amostra corroboram com a hipótese de complexação.

\subsection{Testes de adsorção}

Para realizar os testes de adsorção, o tolueno foi escolhido como representante dos BTEX. Nesse caso, conforme melhor descrito na parte experimental, quantidades específicas e variáveis de tolueno foram adicionadas a amostras de água destilada $(20,0 \mathrm{~mL})$ a fim de se mimetizar sistemas contaminados. Essas amostras foram acondicionadas em frascos hermeticamente fechados, com septo, para que não houvesse nenhuma perda por evaporação. Em seguida, a concentração de tolueno em cada 
amostra foi determinada por análise de TOC, conforme descrito na seção experimental. Após essa etapa, uma quantidade de nanopartículas funcionalizadas $(5,0 \mathrm{mg})$ foram adicionadas em cada frasco e o sistema ficou sob tombamento por 12 h. Após esse tempo, as NP's foram cuidadosamente separadas com auxílio de um ímã e a concentração de tolueno foi novamente determinada por TOC. A figura 22 ilustra as etapas desse processo.

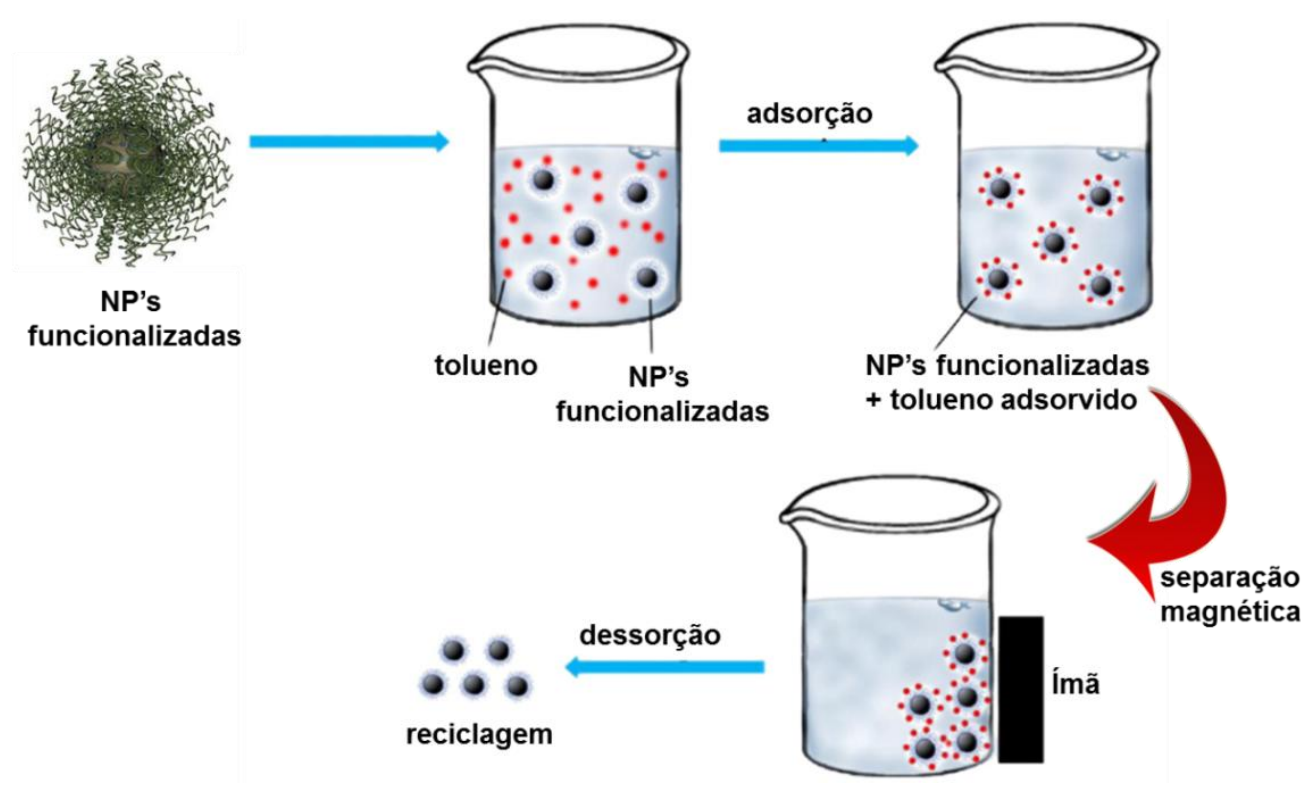

Figura 22 - Representação da dispersão das nanoparticulas funcionalizadas com PDMS em solução contendo tolueno. Após a adsorção do contaminante pelas nanopartículas é possível reciclar o material separando-as do efluente utilizando um imã.

Para avaliar a eficiência de remoção, um gráfico do percentual de tolueno removido foi plotado em função da relação da massa de nanopartículas sobre a massa de tolueno em cada amostra foi plotado, conforme mostrado na figura 23. Esse percentual de remoção foi calculado pela relação $\left(C_{0}-C_{e}\right) / C_{0}$, em que $C_{0}$ é a concentração nominal (inicial) de tolueno e $C_{e}$ é a concentração de equilíbrio de tolueno, após interação com as nanopartículas. Esses dados estão listados na tabela 2. 


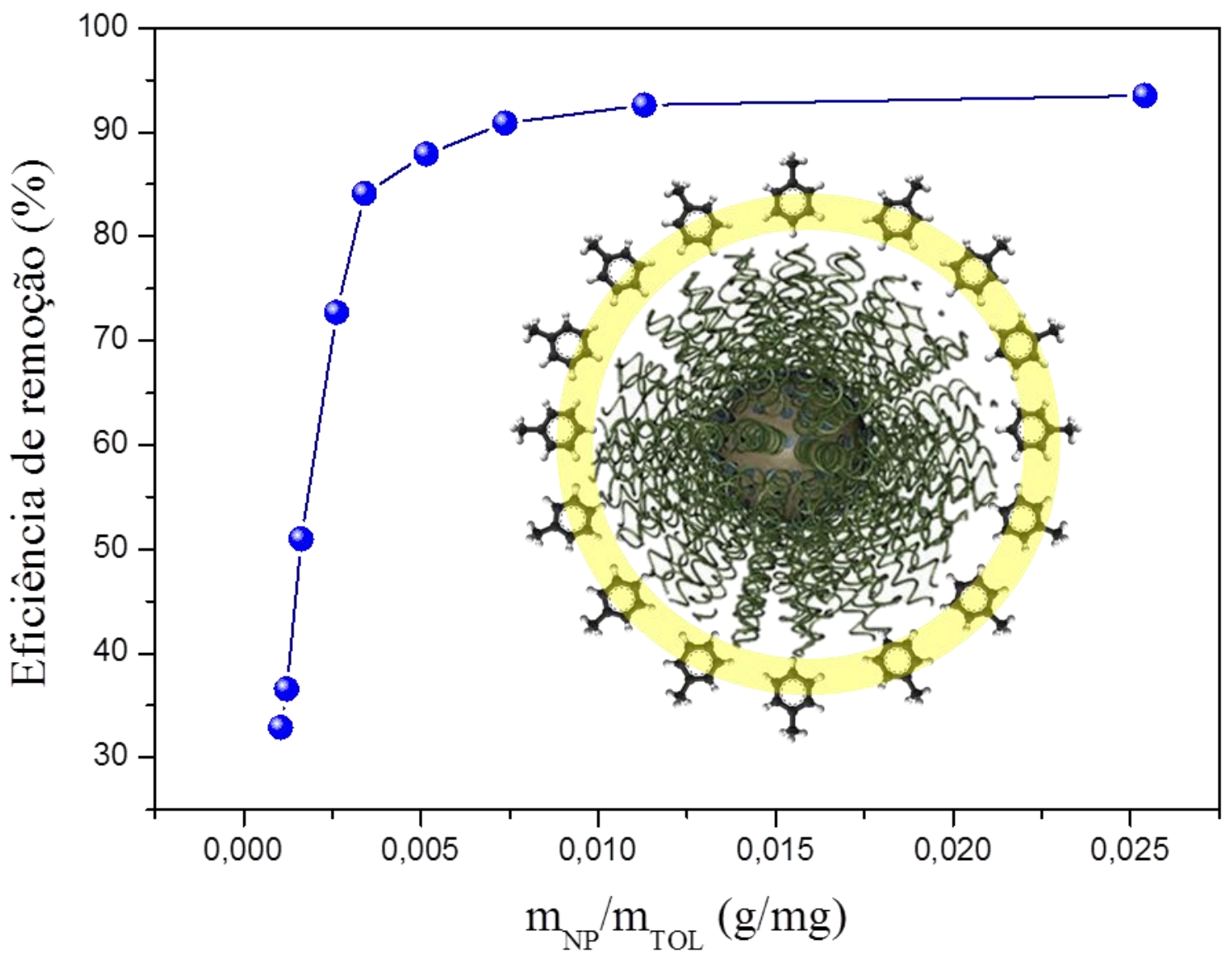

Figura 23- Gráfico do percentual de tolueno removido em função da relação da massa de nanopartículas sobre a massa de tolueno em cada amostra.

Como é possível observar, à medida que a quantidade de NP's aumenta em relação à de tolueno, a eficiência de remoção desse solvente aumenta rapidamente, mas atingindo um patamar em cerca de $93 \%$, quando se tem uma proporção de cerca de 100 vezes, em massa, de NP's em relação ao tolueno. Portanto, em uma primeira análise, esse sistema se aparenta bastante promissor para a função de remoção de BTEX em águas contaminadas. 


\begin{tabular}{cccccc}
\hline $\begin{array}{c}\boldsymbol{C}_{\mathbf{0}} \\
(\mathbf{m g} / \mathbf{L})\end{array}$ & $\begin{array}{c}\boldsymbol{C}_{\mathrm{e}} \\
(\mathbf{m g} / \mathbf{L})\end{array}$ & $\begin{array}{c}\boldsymbol{q}_{\mathrm{e}} \\
(\mathbf{m g} / \mathbf{g})\end{array}$ & $\begin{array}{c}\boldsymbol{C}_{\mathrm{e}} / \boldsymbol{q}_{\mathrm{e}} \\
(\mathbf{g} / \mathbf{L})\end{array}$ & $\begin{array}{c}\boldsymbol{m}_{\mathrm{NP}} / \boldsymbol{m}_{\mathrm{TOL}} \\
(\mathbf{g} / \mathbf{m g})\end{array}$ & $\begin{array}{c}\left(C_{0}-C_{e}\right) / C_{0} \\
(\boldsymbol{\%})\end{array}$ \\
\hline 9,84 & 0,64 & 36,80 & 0,017322 & 0,0254 & 93,52 \\
22,11 & 1,64 & 81,88 & 0,02007 & 0,0113 & 92,57 \\
33,88 & 3,09 & 123,16 & 0,025089 & 0,0074 & 90,88 \\
48,50 & 5,87 & 170,50 & 0,034438 & 0,0052 & 87,89 \\
73,25 & 11,65 & 246,40 & 0,047283 & 0,0034 & 84,09 \\
95,33 & 26,01 & 277,28 & 0,093815 & 0,0026 & 72,71 \\
153,65 & 75,32 & 313,31 & 0,240398 & 0,0016 & 50,98 \\
206,28 & 130,77 & 302,04 & 0,432934 & 0,0012 & 36,61 \\
238,22 & 159,87 & 313,42 & 0,510082 & 0,0010 & 32,89 \\
\hline
\end{tabular}

Tabela 2 - Parâmetros de concentração e massa para os testes de adsorção.

Entretanto, para se otimizar a aplicação das nanopartículas funcionalizadas na adsorção desse tipo de molécula, é necessário entender como se dá esse processo. Nesse sentido, as isotermas de adsorção são normalmente usadas para avaliar, quali e quantitativamente, a interação entre adsorventes e adsorvatos quando o processo de adsorção atinge o equilíbrio. A figura 24 mostra a isoterma de adsorção de tolueno, nas condições experimentais acima especificadas, em NP's magnéticas funcionalizadas com PDMSCOOH. 


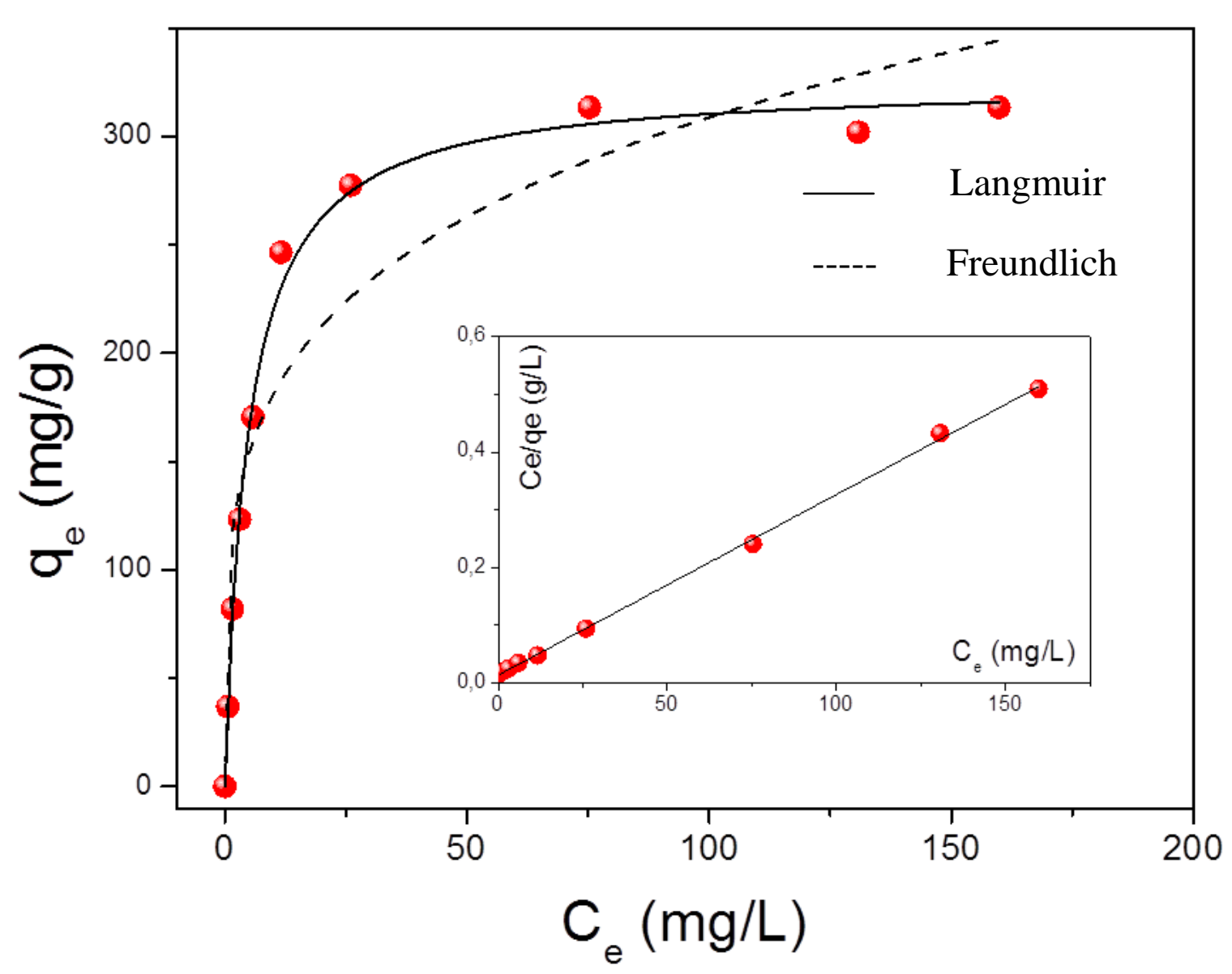

Figura 24 - Isoterma de adsorção de tolueno pelas NPM.

Nesse gráfico, a capacidade de adsorção das NP's funcionalizadas, calculada como $q_{e}=\frac{\left(C_{0}-C_{e}\right) V}{m}$, em que $V$ e $m$ são, respectivamente, o volume de solução (L) e a massa de adsorvente (g), é plotada versus a concentração de equilíbrio de adsorvato. A adsorção tende a atingir um equilíbrio em concentrações maiores de tolueno. Isso pode ser devido ao aumento do número de moléculas de adsorvato e, portanto, a sua maior difusão na superfície das nanopartículas. Para investigar o mecanismo do processo de adsorção, os modelos de Langmuir e de Freundlich são os mais comumente utilizados ${ }^{69}$.

O modelo de Langmuir assume que a adsorção ocorre em uma superfície homogênea, com um recobrimento homogêneo e sem subsequentes interações entre a 
espécie adsorvida e superfície. A equação forma linearizada de Langmuir é dada por c, em que $q_{e}$ e $C_{e}$, já anteriormente definidos, são a quantidade de tolueno adsorvida por gramas de NP's (mg/g) e concentração de equilíbrio de tolueno $(\mathrm{mg} / \mathrm{L})$, respectivamente, $K_{L}$ é a constante de Langmuir $(\mathrm{L} / \mathrm{mg})$ - relacionada à afinidade adsorvente/adsorvato - e $q_{m}$ representa a máxima capacidade de adsorção (mg/g). Os valores de $K_{L}$ e $q_{m}$ podem ser facilmente calculados pelo ajuste do gráfico de $q_{e}$ versus $C_{e}$, ou pela inclinação e interceptação da reta do gráfico de $C_{e} / q_{e}$ versus $C_{e}$, conforme mostrado na figura 24 , em que as linhas sólidas representam o ajuste dos pontos experimentais (vermelhos), obtido pelo modelo de Langmuir.

O modelo de Freundlich é um modelo empírico baseado na adsorção em multicamadas em superfícies heterogêneas. A equação é comumente descrita como: $q_{e}=K_{F} C_{e}^{1 / n}$, em que $K_{F}$ é a constante de Freundlich, associada à capacidade de adsorção, e $1 / n$ é a intensidade de adsorção. A magnitude de $1 / n$ quantifica a tendência de adsorção e o grau de heterogeneidade da superfície. Valores de $n>1$ sugerem adsorção favorável e, aumento dessa capacidade, pela criação de novos sítios de adsorção. $K_{F}$ e $n$ podem ser obtidos do ajuste do gráfico de $q_{e}$ versus $C_{e}$, ou pela interceptação inclinação da reta da equação de Freundlich na forma linear $\ln q_{e}=\ln K_{F}+\frac{1}{n} \ln C_{e}$, no gráfico de $\ln q_{e}$ versus $\ln C_{e}$. Esse modelo também foi usado para ajustar os dados experimentais no gráfico da figura 24 (linha tracejada).

Os parâmetros calculados a partir dos ajustes dos dados experimentais com auxílio dos modelos de Langmuir e Freundlich estão listados na tabela 3. Os resultados indicam que, nesse caso, o modelo que melhor ajusta os dados é o de Langmuir, que 
rende um parâmetro $R^{2}>0,99$. Além disso, a capacidade máxima de adsorção dos nanomateriais aqui sintetizados $\left(q_{\mathrm{m}}=325,2 \mathrm{mg} / \mathrm{g}\right)$ é maior que algumas observadas para adsorção de tolueno em outros materiais, como em nanotubos de carbono $\left(q_{\mathrm{m}} \sim 100\right.$ mg/g)70. Como o sistema estudado se comporta de acordo com o Modelo de Langmuir, pode-se calcular o parâmetro de equilíbrio, dado pela equação $R_{L}=\frac{1}{1+K_{L} C_{0}}$. Nesse caso, se $R_{\mathrm{L}}>1$, a adsorção é desfavorável e se $0>R_{\mathrm{L}}>1$ se torna favorável. Para a concentração de 9,84 mg/L, por exemplo, $R_{\mathrm{L}} \sim 0,3$ o que indica uma adsorção favorável. Entretanto, é necessário fazer estudos mais aprofundados em função da cinética e da termodinâmica de adsorção, correlacionando-os com novas caracterizações de superfície das nanopartículas, para melhor compreender os sistemas aqui sintetizados e, até mesmo, encontrar rotas para otimizar sua aplicação na remoção de poluentes orgânicos (BTEX) em amostras de água contaminadas.

\begin{tabular}{ccccccc}
\hline & Langmuir & & & \multicolumn{3}{c}{ Freundlich } \\
\cline { 1 - 2 } \cline { 5 - 6 } $\begin{array}{c}K_{L} \\
(\mathrm{~L} / \mathrm{mg})\end{array}$ & $\begin{array}{c}q_{m} \\
(\mathrm{mg} / \mathrm{g})\end{array}$ & $R^{2}$ & & $K_{F}$ & $n$ & $R^{2}$ \\
\cline { 1 - 2 } \cline { 5 - 7 } & 325,2 & 0,9952 & & 106,0 & 4,308 & 0,8829 \\
\hline
\end{tabular}

Tabela 3 - Parâmetros de adsorção obtidos do ajuste matemático das isotermas. 


\section{Conclusões e Perspectivas}




\section{Conclusões e perspectivas}

- Nanopartículas de ferrita de cobalto e manganês foram sintetizadas por coprecipitação térmica, a partir de soluções de $\mathrm{Fe}^{3+}, \mathrm{Co}^{2+}$ e $\mathrm{Mn}^{2+}$, utilizando $\mathrm{NaOH}$ como agente precipitante. Após acidificação e tratamento hidrotérmico de superfície (com nitrato férrico), um controle de $\mathrm{pH}$ e força iônica permitiu a dispersão dessas nanopartículas e obtenção de um sol de concentração de aproximadamente 320 mg/mL;

- Para funcionalização, condições ótimas de $\mathrm{pH}$ e concentrações foram estabelecidas a partir das propriedades ácido-base do ligante PDMSCOOH e da superfície das nanopartículas. Após funcionalização, as NP's passaram a apresentar característica hidrofóbica, sendo facilmente dispersáveis em solventes orgânicos apolares, como é o caso do tolueno, um dos componentes dos BTEX, aqui investigado como poluente;

- As nanopartículas magnéticas tiveram a estrutura cristalográfica confirmada por DRX, com um tamanho cristalino de $\sim 14 \mathrm{~nm}$. Por MET, nanomateriais aproximadamente esféricos foram observados, com tamanho médio típico de $\sim 13 \mathrm{~nm} \quad(0,20 \mathrm{em}$ polidispersão). O comportamento das nanopartículas foi do tipo ferromagnético, com magnetização de saturação maior que $60 \mathrm{emu} / \mathrm{g}$ e campo coercitivo e magnetização remanente iguais a 200 Oe e $11 \mathrm{emu} / \mathrm{g}$, respectivamente;

- A efetividade da funcionalização pôde ser evidenciada por medidas de DRX e MET e confirmada por medidas de FTIR, que indicaram um modelo de nanopartículas magnéticas recobertas pelas moléculas de $\mathrm{PDMSCOOH}$ via complexação dos metais superficiais pelos grupos carboxila. A magnetização de saturação diminuiu em cerca de 8\%, e a área de histerese aumentou após funcionalização. Além disso, por medidas de magnetização, estimou-se uma fração em massa de 0,11 em polímero (PDMSCOOH) no nanocompósito; 
- Uma eficiência de remoção do hidrocarboneto, maior que 90\%, foi observada em amostras de água contaminadas com esse composto. O tratamento matemático das isotermas de adsorção permitiu calcular a capacidade máxima dessas nanopartículas em adsorver tolueno, em amostras simuladas de água contaminada com esse hidrocarboneto. O modelo que melhor ajustou os resultados foi o de Langmuir e sugere uma quantidade máxima de adsorção igual a $325 \mathrm{mg}$ de tolueno por grama de nanopartículas, nas condições experimentais utilizadas;

- Esses resultados são bastante promissores, já que o material apresenta uma capacidade de adsorção maior ou comparável a de nanomateriais já utilizados. Entretanto, o sistema empregado nesse trabalho apresenta a vantagem de ser magnético e, portanto, mais facilmente manipulável nas separações e reutilização dos nanoadsorbentes. Apesar disso, um estudo mais aprofundado deve ser feito para otimizar sua aplicação. Por exemplo, uma investigação quantitativa da funcionalização e uma avaliação da cinética de adsorção, devem ser executadas para melhor compreensão desse fenômeno;

- Além desses estudos ainda necessários é importante salientar que esse processo tem de ser transferido e estudado em maior escala. Para tal, a construção de um protótipo de baixo custo se torna interessante para futuros trabalhos. 


\section{Referências}

Bibliográficas 
${ }^{1}$ TRATNYEK, P. G.; JOHNSON, R. L. Nanotechnologies for environmental cleanup. Nano Today, v. 1, p. 44, 2006.

${ }^{2}$ SAVAGE, N.; DIALLO, M. S. Nanomaterials and water purification: Opportunities and challenges. Journal of Nanoparticle Research, v.7, p. 331-342, 2005.

${ }^{3}$ MAYO, J.T. et al. The effect of nanocrystalline magnetite size on arsenic removal. Science and Technology of Advanced Materials, v.8, p.71-75, 2007.

${ }^{4}$ APBLETT, A.W. et al. Proceedings of the 8th International Environmental. Petroleum Consortium, 2001.

${ }^{5}$ PORTARIA N ${ }^{\circ}$ 1339, DE 18 DE NOVEMBRO DE 1999.

\section{${ }^{6}$ MINISTERIO DA SAUDE}

${ }^{7}$ SILVA, R.L.B. et al. A study of groundwater contamination with organic fuels and potential public health impact in Itaguaí, Rio de Janeiro State, Brazil. Caderno de Saúde Pública, Rio de Janeiro. p.1599-1607, Nov-Dez 2002.

${ }^{8}$ KONIECZNY, K. et al. Removal of volatile compounds from the wastewaters by use of pervaporation. Halkidiki, Greece, v.223, p.344-348, 2008.

${ }^{9}$ WILSON, K. S. et al. Polydimethylsiloxane-magnetite nanoparticle complexes and dispersions in polysiloxane carrier fluids. Polymers for Advanced Technologies. v. 16, p. 200-211, 2005.

10 DUMITRU, I. et al. The influence of Mn doping level on magnetostriction coefficient of cobalt ferrite Ovidiu Caltun. Journal of Magnetism and Magnetic Materials. V.316, p. e618-e620, 2007.

${ }^{11}$ Gomes, J. A. et al. Synthesis of Core-Shell Ferrite Nanoparticles for Ferrofluids: Chemical and Magnetic Analysis. Journal of Physicochemical, p. 6220-6227, 2008.

${ }^{12}$ ZHAO, Y. X . et al.Study of polydiethylsiloxane-based ferrofluid with excellent frost resistance property. Journal of Magnetism and Magnetic Materials, v.321, p. 377 - 381, 2009.

${ }^{13}$ BATRA, A.; COHEN, C.; DUNCAN, T. M. Synthesis and Rheology of Tailored Poly(dimethylsiloxane) Zinc and Sodium Ionomers. New York, Cornell University, Ithaca,v.39, p. 426-438, 2006

${ }^{14}$ Rifai, H.S. and P.B. Bedient "Modeling Contaminant Transport and Biodegradation in Ground Water" Advances in Environmental Science Groundwater Contamination, Volume I: Methodology and Modeling, Springer-Verlag, New York, NY (1994). 
${ }^{15}$ LACERDA, L. D. D.; MALM, O. Contaminação por mercúrio em ecossistemas aquáticos: uma análise das áreas críticas. Estudos Avançados, v. 22, p. 173-190, 2008.

${ }^{16}$ Steinkellner, H. et al. Genotoxic effects of heavy metals: comparative investigation with plant bioassays. Environ Mol Mutagen, v.31, n.1, p. 83-91,1998.

${ }^{17}$ PETROBRAS (Petróleo Brasileiro S.A.), 1995. Relatório Anual de Atividades. Rio de Janeiro: Petrobras.

${ }^{18}$ BICALHO, K.V. Dissolução de Gasolina em Presença de Água e Etanol. 1997. Tese de Doutorado - Faculdade de Engenharia Civil, Pontifícia Universidade católica do Rio de Janeiro. Rio De Janeiro.

19 DIAS, D.S. e RODRIGUES, A. P. "Petróleo, livre mercado e demandas sociais”. Instituto Liberal: Rio de Janeiro, Rio de Janeiro,1994.

20 BERTON, S. M. H. Estudo da toxicidade de hidrocarbonetos monoaromaticos utilizando Vibrio fischeri, Daphnia magna e Desmodesmus subspicatus. 2013. $153 \mathrm{f}$. Dissertação (Mestrado em Ciência e Tecnologia Ambiental) - Universidade Tecnológica Federal do Paraná, Curitiba, 2013.

${ }^{21}$ CADORIN, M. Comunicação pessoal, Presidente da Fundação de Meio Ambiente, Joinville, SC, 1996.

${ }^{22}$ CORSEUIL, H.X. Enhanced Degradation of Monoaromatic Hydrocarbons in Sandy Aquifer Materials by Inoculation Using Biologically Active Carbon Reactors. PhD dissertation, Ann Arbor, MI, EUA, 1992.

${ }^{23}$ Resolução do Conselho Interministerial do Açúcar e do Álcool (CIMA), n. ${ }^{\text {3 35, de } 22}$ de fevereiro de 2006, publicada no Diário Oficial da União em 23 de fevereiro de 2006.

${ }^{24} \mathrm{http} / / / \mathrm{www}$. br.com.br/wps/portal/portalconteudo/produtos/automotivos/gasolina/!ut/p/ c4/04_SB8K8xLLM9MSSzPy8xBz9CP0os3hLf0N_P293QwP3YE9nAyNTD5egIEcnQ 4MgQ_2CbEdFAGTIInk!/?PC_7_9O1ONKG10GSIC025HDRRAB10F4000000_WC

M_CONTEXT=/wps/wcm/connect/portal+de+conteudo/produtos/automotivos/gasolina/ composicao+da+gasolina. 05-06-2015 as 10:22

${ }^{25}$ CORSEUIL, H.X., WEBER, W.J., JR. Potential Biomass Limitations on Rates of Degradation of Monoaromatic Hydrocarbons by Indigenous Microbes in Subsurface Soils, Wat. Res., v.28, p.1407-1414, 1994.

${ }^{26}$ CETESB. Proposta para limite de intervenção de qualidade do solo no Estado de São Paulo. 2000

${ }^{27}$ SHACKELFORD, CharleS. Remediation of contaminated land: In Overview. 11th Panamerican Conference Soil Mechanics \& Geotechnical Engineering. Foz do Iguaçu, PR, 1999. 
${ }^{28}$ EVDOKIMOVA, G. A. et al. . Soils and waste water purification from oil products using combined methods under the North conditions. J Environ Sci Health A Tox Hazard Subst Environ Eng, v. 47, n. 12, p. 1733-8, 2012.

${ }^{29}$ Cetesb, 2013, modificado. EPA, 2014, modificado.

${ }^{30}$ DiGIULIO, D.C. \& VARADHAN, R. Development of recommendations and methods to support assessment of soil venting performance and closure. U.S. EPA, ORD, EPA/600/R-01/070, 2001.

${ }^{31}$ MARIANO, A.P. Avaliação do potencial de biorremediação de solos e de águas subterrâneas contaminados com óleo diesel. Tese de Doutorado, São Paulo: Instituto de Geociências e Ciências Exatas, Universidade Estadual Paulista, 2006.

32 BENTO, F. M.; CAMARGO, F. A. O.; OKEKE, B. Bioremediation of soil contaminated by diesel oil. Brazilian Journal of Microbiology, v.34, p. 65-68, 2003.

${ }^{33}$ CORNELL, R. M.; SCHWERTMANN, U. The iron oxides: structure, properties, reactions, occurrence and uses. 1. ed. Weinheim - Alemanha: VHC, p.573, 1996.

${ }^{34}$ CLAUDINO, A. Preparação de carvão ativado a partir de turfa e sua utilização na remoção de poluentes. Dissertação de Mestrado, Florianópolis. Universidade federal de Santa Catarina, 2003.

${ }^{35}$ QUINA, Frank,H. Nanotecnologia e o meio ambiente: perspectivas e riscos. Quimica Nova, São Paulo, v.27,n.6,p.1028-1029,2004.

${ }^{36}$ U. S. Environmental Protection Agency (EPA), STAR Progress Review Workshop, "Nanotechnology and the Environment: Applications and Implications", 2002.

${ }^{37}$ DIANDRA, L. et al. Magnetic properties of nanostructured materials. Chem. Mater., v. 8, p. 1770 - 1783, 1996.

${ }^{38}$ CALDEIRA, L. et al. Remediação in situ de solos e águas subterrâneas com uso de nanopartículas de ferro zero valente: Avaliação preliminar. Geonovas, n. 26, p. 55-65, 2013.

${ }^{39}$ LOPES, M. C. et al. Espumados Magnetizáveis Úteis em Processos de Recuperação Ambiental. Polímeros,v.20,n.especial,p.359-365,2010.

${ }^{40}$ SILVA, M. F. et al. Aplicação de óxidos de ferro nanoestruturados como adsorventes e fotocatalisadores na remoção de poluentes de águas residuais. Química Nova, v.38, n.3, p.393-398, 2015. 
${ }^{41}$ ZHAO, X. et al. Polymer-supported nanocomposites for environmental application: A review. Chemical Engineering Journal, v. 170, p. 381-394, 2011.

${ }^{42}$ FERNANDES, M.T.C.; KAWACHI, E.Y. Influência na quantidade de amônio na síntese de nanopartículas de óxidos de ferro por microemulsão. Química Nova, v. 6, p.1242-1246, 2010.

${ }^{43}$ MARCHEGIANI, G. et al. Ultrason. Sonochem, v. 19, p. 877, 2012.

44 TEIXEIRA, A. P. C. et al. . Iron: a versatile element to produce materials for environmental applications. Journal of the Brazilian Chemical Society, v. 23, p. 1579-1593, 2012.

${ }^{45}$ DIAS, J.C. et al. Refletividade de fótons microondas por tintas poliuretânicas aditadas com Ferritas de NiZn e MnZn. Revista de Física Aplicada e Instrumentação, v.18, p.24-33, 2005.

46 APHESTEGUY, J.C. et al. Characterization o nonosized spinel ferrite powders synthesized by coprecipitation and autocombustion method. Journal of Alloys and Compounds, v. 495, p. 509-512, 2010.

47 FAUCONNIER, A. et al. Synthesis of Aqueous Magnetic Liquids by Surface Complexation of Maghemite Nanoparticles." Journal of Molecular Liquids, v.83, p. 23-42, 1999.

${ }^{48}$ SUN, X.H. et al. Size-Controlled Synthesis of Magnetite (Fe3O4) Nanoparticles Coated with Glucose and Gluconic Acid from a Single Fe(III) Precursos by a Sucrose Bifunctional Hydrothermal Method. Journal of physicochemical C, v. 113, p. 160016008, 2009.

${ }^{49}$ KEKKONEN, V. et al. Synthesis and Characterizatoin of biocompatible magnetic glyconanoparticles. Journal of Magnetism and Magnetic Materials, v. 321, p. 13931396, 2009.

${ }^{50}$ CAREÑO, N. L. V. et al. Nanocompósitos cerâmicos a partir do processo de moagem mecânica de alta energia. Química Nova, v.31, p. 962-968, 2008.

${ }^{51}$ BRITO, V. L. O. Ferritas Ni-Zn: breve revisão sobre o processo convencional de fabricação e as propriedades permeabilidade magnética e constante dielétrica. Cerâmica, v. 52, p.221, 2006.

${ }^{52}$ GOMES, J. A. et al. . Rietveld structure refinement of the cation distribution in ferrite fine particles studied by X-ray powder diffraction. Journal of Magnetism and Magnetic Materials, v. 289, p. 184-187, 2005. 
${ }^{53}$ CAMPOS, A. F. C. et al. . Nanoparticles superficial density of charge in electric double-layered magnetic fluid: A conductimetric and potentiometric approach. European Physical Journal E, v. 6, n. 1, p. 29-35, 2001.

${ }^{54}$ AQUINO, R. et al. Magnetization Temperature Dependence and Freezing of Surface Spins in Magnetic Fluids Based on Ferrite Nanoparticles. Physical Review B, p. 72, 2005.

${ }^{55}$ GOMES, J. A. et al. Rietveld structure refinement of the cation distribution in ferrite fine particles studied by X- ray powder diffraction, Journal of Magnetism and magnetic Materials, v. 289 , p. 184-187, 2005.

${ }^{56}$ CAMPOS, A. F. C. Contribuição ao Estudo da Densidade Superficial de Carga na Estabilidade de Coloides Magnéticos: Uma Abordagem Eletroquímica. Tese de Doutorado, Universidade de Brasília, 2005.

57 SOUSA, E. C. et al. Enhanced surface anisotropy evidenced by Mossbauer spectroscopy in nickel ferrite nanoparticles, J Journal of Magnetism and magnetic Materials , v. 272, p. E1215-E1217, 2004.

${ }^{58}$ GOMES, J. A. et al. . Rietveld structure refinement of the cation distribution in ferrite fine particles studied by X-ray powder diffraction. Journal of Magnetism and Magnetic Materials, v. 289, p. 184-187, 2005.

59 SOUSA, E. C. et al. . Enhanced surface anisotropy evidenced by Mossbauer spectroscopy in nickel ferrite nanoparticles. Journal of Magnetism and Magnetic Materials, v. 272, p. E1215-E1217, 2004.

${ }^{60}$ CAMPOS, A. F. C. et al. . Using speciation diagrams to improve synthesis of magnetic nanosorbents for environmental applications. Bulletin of Materials Science, v. 34, n. 7, p. 1357-1361, 2011.

${ }^{62}$ SAENGER, J. F. et al. . Investigation of the anisotropy in frozen nickel ferrite ionic magnetic fluid using magnetic resonance. Journal of Magnetic Resonance, v. 134, n. 1, p. 180-183, 1998.

${ }^{63}$ KRIEBLE, K. et al. . Mossbauer spectroscopy investigation of mn-substituted coferrite (CoMnxFe2-xO4). Journal of Applied Physics, v. 97, n. 10, 2005.

${ }^{64} \mathrm{KIM}, \mathrm{C}$. S. et al. . Growth of ultrafine Co-Mn ferrite and magnetic properties by a sol-gel method. Journal of Applied Physics, v. 85, n. 8, p. 5223-5225, 1999.

${ }^{65}$ SHOBANA, M. K.; SANKAR, S.; RAJENDRAN, V. Characterization of $\mathrm{Co} 0.5 \mathrm{Mn} 0.5 \mathrm{Fe} 2 \mathrm{O} 4$ nanoparticles. Materials Chemistry and Physics, v. 113, n. 1, p. 10-13, 2009. 
${ }^{66}$ SOUSA, M. H. et al. Use of Raman micro-spectroscopy in the characterization of $\mathrm{M}(\mathrm{II}) \mathrm{Fe} 2 \mathrm{O} 4(\mathrm{M}=\mathrm{Fe}, \mathrm{Zn})$ electric double layer ferrofluids, Journal Raman Spectroscopy, v. 31, p. 185-191, 2000.

67 JACINTHO, G. V. M. et al. Structural Investigation of MFe2O4 (M = Fe, Co) Magnetic Fluids, Journal of physicochemical C, v.113,p. 7684-7691, 2009.

${ }^{68}$ VESTAL, C. R.; ZHANG, Z. J. Effects of surface coordination chemistry on the magnetic properties of $\mathrm{MnFe} 2 \mathrm{O} 4$ spinel ferrite nanoparticles. Journal of the American Chemical Society, v. 125, n. 32, p. 9828-9833, 2003

${ }^{69}$ PETZOLD, G.; SCHWARZ, S. Investigation of an improved deinking process of waste paper - The influence of surface tension and charge in suspension on ink removal. Colloids and Surfaces a-Physicochemical and Engineering Aspects, v. 480, p. 398404, 2015.

${ }^{70}$ YE, C. Z.; ARIYA, P. A. Co-adsorption of gaseous benzene, toluene, ethylbenzene, m-xylene (BTEX) and $\mathrm{SO} 2$ on recyclable $\mathrm{Fe} 3 \mathrm{O} 4$ nanoparticles at $0-101 \%$ relative humidities. Journal of Environmental Sciences-China, v. 31, p. 164-174, 2015. 